\title{
COVID-19 lockdown: a boon in boosting the air quality of major Indian Metropolitan Cities
}

\author{
Devendra Singh Rathore $\mathbb{C}$ - Chirmaie Nagda • Bhavya Singh Shaktawat • \\ Tanushree Kain • Chandrapal Singh Chouhan • Rakeshwar Purohit • \\ Harish · Rama Kanwar Khangarot • Girima Nagda • Lalit Singh Jhala
}

Received: 4 July 2020/Accepted: 3 November 2020/Published online: 17 November 2020

(C) Springer Nature B.V. 2020

\begin{abstract}
The COVID-19 lockdown has not only helped in combating the community transmission of SARS-CoV-2 but also improved air quality in a very emphatic manner in most of the countries. In India, the first phase of COVID-19 lockdown came into force on March 25, 2020, which was later continued in the next phases. The purpose of this study was to investigate the result of lockdown on air quality of major metropolitan cities-Delhi, Mumbai, Kolkata, Chennai, Bengaluru, Hyderabad, Jaipur, and Lucknowfrom March 25 to May 3, 2020. For this study, the concentration of six criteria air pollutants $\left(\mathrm{PM}_{2.5}\right.$, $\mathrm{PM}_{10}, \mathrm{CO}, \mathrm{NO}_{2}, \mathrm{SO}_{2}$, and $\mathrm{O}_{3}$ ) and air quality index during the COVID-19 lockdown period was compared with the same period of the previous year 2019. The results indicate a substantial improvement in air
\end{abstract}

D. S. Rathore $(\bowtie) \cdot$ B. S. Shaktawat · T. Kain

Department of Environmental Sciences, Mohanlal Sukhadia University, Udaipur, Rajasthan 313001, India e-mail: dsrathoremlsu@gmail.com

C. Nagda · G. Nagda

Department of Zoology, Mohanlal Sukhadia University, Udaipur, Rajasthan 313001, India

C. S. Chouhan

Department of Mathematics and Statistics, Bhupal

Nobles' University, Udaipur, Rajasthan 313001, India

R. Purohit

Department of Mathematics and Statistics, Mohanlal

Sukhadia University, Udaipur, Rajasthan 313001, India quality with a drastic decrease in the concentration of $\mathrm{PM}_{2.5}, \mathrm{PM}_{10}, \mathrm{CO}$, and $\mathrm{NO}_{2}$, while there is a moderate reduction in $\mathrm{SO}_{2}$ and $\mathrm{O}_{3}$ concentration. During the lockdown period, the maximum reduction in the concentration of $\mathrm{PM}_{2.5}, \mathrm{PM}_{10}, \mathrm{CO}, \mathrm{NO}_{2}, \mathrm{SO}_{2}$, and $\mathrm{O}_{3}$ was observed to be $-49 \%$ (Lucknow), $-57 \%$ (Delhi), $-75 \%$ (Mumbai), $-68 \%$ (Kolkata), $-48 \%$ (Mumbai), and - 29\% (Hyderabad), respectively. The value of the air quality index (AQI) also dwindled significantly during the COVID-19 lockdown period. The maximum decline in AQI was observed - $52 \%$ in Bengaluru and Lucknow. The order of AQI was satisfactory $>$ moderate $>$ good $>$ poor and the frequency order of prominent pollutants was $\mathrm{O}_{3}>\mathrm{PM}_{10}$ $>\mathrm{PM}_{2.5}>\mathrm{CO}>\mathrm{NO}_{2}>\mathrm{SO}_{2}$ during the lockdown period in all the aforementioned metropolitan cities.

Harish

Department of Botany, Mohanlal Sukhadia University,

Udaipur, Rajasthan 313001, India

R. K. Khangarot

Department of Chemistry, Mohanlal Sukhadia University, Udaipur, Rajasthan 313001, India

L. S. Jhala

Department of Geography, Jai Narain Vyas University, Jodhpur, Rajasthan 342011, India 


\section{Graphic abstract}

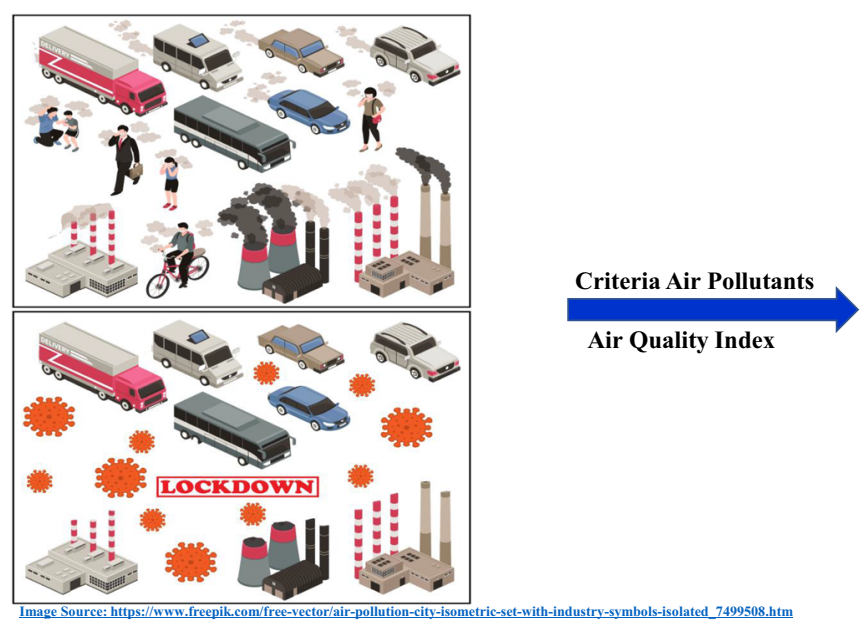

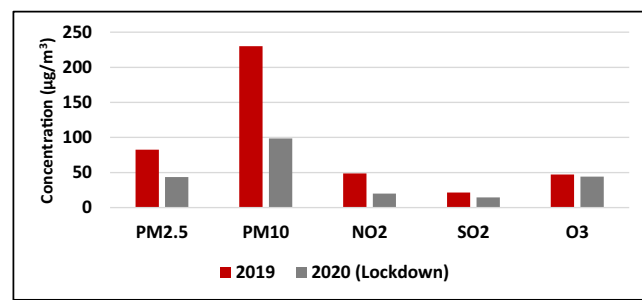

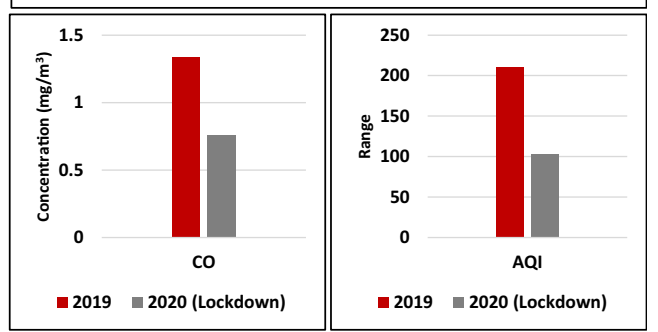

Keywords COVID-19 - Lockdown - Criteria pollutants · Air quality index · Metropolitan cities · Prominent pollutant

\section{Introduction}

The rapid transmission of the COVID-19 pandemic has become a major health threat globally. In late December 2019, an epidemic of pneumonia linked with novel coronavirus disease-2019 (COVID-19) (Huang et al. 2020a, b; Wu et al. 2020) that has its epicenter in Wuhan, China, has spread over 215 countries worldwide (WHO 2020a). The COVID-19 epidemic was declared a public health emergency at a global level by the World Health Organization (WHO) on Jan 30, 2020 (WHO 2020b). The COVID-19 cases burst at an alarming rate with significant mortality (Wang et al. 2020a, b) and have impacted human life and the world economy. The transmission of COVID19 has mostly occurred between people via respiratory droplets and contact routes (Burke et al. 2020; Chan et al. 2020; Li et al. 2020; Liu et al. 2020a, b; WHO 2020c).

Breaking the chain of transmission of SARS-CoV-2 via social isolation is the only way to control the exponential spread of the COVID-19 pandemic. Social distancing is a prevention strategy to control infection by discouraging/decreasing contact with infected and non-infected people, contaminated surfaces, and also among the general public to slow down the rate of spread of disease. Many countries have imposed dramatic interventions like lockdown of the entire country, curtailing human interaction, restriction on public gatherings, and public transportations to adopt social distancing (He et al. 2020). The first lockdown was intruded in Wuhan, China, and later followed by other countries (Jing 2020). Indian government locked the country for fourteen hours in the name of "Janta Curfew" after Prime Minister's call on March 22, 2020. After Janta Curfew, India went into complete lockdown on March 25 for 21 days followed by the next lockdown for 19 days from April 15 to May 3, the third phase from May 4 to May 17 and the fourth phase from May 18 to May 31, 2020. The lockdown restricted movement of the public and shut down commercial and industrial establishments that adversely affected the growth and economy of India, but on the flip side, our society and environment gained substantial benefits that would be advantageous to the layperson and moderately counterbalance the cost of this pandemic. Due to the lockdown, dramatic positive changes have happened in the air quality of the world that showed a glimpse of a cleaner world. As per media intelligence, a massive reduction in air pollution due to lockdown has been observed in numerous countries by satellite pictures. A few scientific researchers also reported a significant augmentation in air quality because of COVID-19 lockdown worldwide (Cadotte 2020; Dantas et al. 2020; He et al. 2020; 2020a, b; Isaifan 2020; 
Kerimray et al. 2020; Muhammad et al. 2020; Ogen 2020; Shrestha et al. 2020; Sicard et al. 2020; Wang and Su 2020; Wang et al. 2020a, b, Zhu et al. 2020) and in India (Chauhan and Singh 2020; Gautam 2020; Mahato et al. 2020; Saadat et al. 2020; Sharma et al. 2020).

Air quality has emerged as an international community health concern in the last few decades. Air pollution is a severe environmental health threat that causes premature mortality and attributes over seven million deaths per annum worldwide (WHO 2020d). Air pollution means the presence of harmful substances in the air such as airborne particulate matter $(\mathrm{PM})$, fine particulate matter $\left(\mathrm{PM}_{2.5}\right)$, coarse particulate matter $\left(\mathrm{PM}_{10}\right)$, and gaseous pollutants like ozone $\left(\mathrm{O}_{3}\right)$, nitrogen dioxide $\left(\mathrm{NO}_{2}\right)$, volatile organic compounds (like benzene), carbon monoxide $(\mathrm{CO})$, sulfur dioxide $\left(\mathrm{SO}_{2}\right)$, etc. (Harrison et al. 2002; Newby et al. 2015). According to $\mathrm{WHO}$, particulate pollution, ground-level $\mathrm{O}_{3}, \mathrm{CO}$, sulfur dioxide $\left(\mathrm{SO}_{2}\right)$, nitrogen oxides $\left(\mathrm{NO}_{\mathrm{x}}\right)$, and lead $(\mathrm{Pb})$ are the six major air pollutants that adversely affect human health and the environment (Ghorani-Azam et al. 2016). Particulate matter (PM) pollutant is responsible for most of the pulmonary and cardiac diseases, and mortality (Sadeghi et al. 2015; Sahu et al. 2014). According to a study of Global Burden of Disease (GBD), $\mathrm{PM}_{2.5}$ is the 5th most vulnerable pollutant responsible for the death of humans worldwide, which triggered 4.2 million deaths in the year 2015 (Cohen et al. 2017). Groundlevel ozone is a probable risk factor for respiratory diseases, predominantly asthma (Gorai et al. 2014), and carbon monoxide toxicity causes hypoxia, apoptosis, and ischemia (Akyol et al. 2014). Exposure of sulfur dioxide is linked with bronchospasm, pulmonary edema, pneumonitis, and acute airway blockage, and nitrogen oxides prominently boost the danger of respiratory problems (Chen et al. 2007). According to WHO, out of the ten most polluted cities worldwide, nine cities are from India. Delhi stands at 6th position in the polluted cities ranking list (Yuda 2019) and holds the 1st rank among all the $\mathrm{PM}_{10}$ polluted cities (Donkelaar et al. 2016; WHO 2018). In India, the concentration of air pollutants is beyond ambient air quality standards of the WHO and Central Pollution Control Board (CPCB), India (Garaga et al. 2018; Mukherjee and Agrawal 2018).

Air quality index is an extensively used tool that describes the severity of air pollution (Nagendra et al.
2007). The air quality index is a single value indicator for the air quality assessment to measure the effects on human health (Bortnick et al. 2002; Kyrkilis et al. 2007; Murena 2004; Thom and Ott 1976).

Hence, in this study, the effects of the lockdown on the air quality of the eight metropolitan cities of India were analyzed. The data of six major criteria air pollutants- $\mathrm{PM}_{2.5}, \mathrm{PM}_{10}, \mathrm{CO}, \mathrm{NO}_{2}, \mathrm{SO}_{2}$, and $\mathrm{O}_{3}-$ and air quality index were collected from the official website of the CPCB, India during the lockdown period from March 25 to May 3, 2020, and the same period of the previous year 2019. For assessing the consequences of the lockdown on air quality and daily concentrations of air pollutants, the data of the COVID-19 lockdown period were compared with the data of the same period of the previous year 2019 that helps in better understanding of the enhancement in air quality as a result of COVID-19 lockdown.

\section{Materials and methods}

\subsection{Selection of the metropolitan cities}

Eight major metropolitan cities-Delhi, Mumbai, Kolkata, Chennai, Bengaluru, Hyderabad, Jaipur, and Lucknow-were selected to estimate the overall air quality status based on (1) total population, (2) previous year's history of air quality status, (3) urban and industrial development, (4) geographical region, and (5) availability of air quality data (Shrestha et al. 2020). The details of region, population, population density, and number of air quality monitoring stations are shown in Table 1, and locations of the selected metropolitan cities are shown in Fig. 1.

\subsection{Selection of air pollutants}

Air quality status can be described by calculating the atmospheric concentrations of six criteria pollutants, i.e., $\mathrm{PM}_{2.5}, \mathrm{PM}_{10}$, carbon monoxide $(\mathrm{CO})$, sulfur dioxide $\left(\mathrm{SO}_{2}\right)$, nitrogen dioxide $\left(\mathrm{NO}_{2}\right)$, and ozone $\left(\mathrm{O}_{3}\right)$ (EPA 2014). The main source of all criteria pollutants is the combustion of fuel in the automobiles and industries, while $\mathrm{O}_{3}$ is being formed by the reaction of primary pollutants in the presence of sunlight. Therefore, to assess the outcome of lockdown on air quality of Indian metropolitan cities, the air pollutant parameters, viz. $\mathrm{PM}_{2.5}, \mathrm{PM}_{10}, \mathrm{CO}, \mathrm{NO}_{2}, \mathrm{SO}_{2}$, and $\mathrm{O}_{3}$, along 
Table 1 Details of selected metropolitan cities of India

\begin{tabular}{lllccc}
\hline $\begin{array}{l}\text { Metropolitan } \\
\text { city name }\end{array}$ & Region & Coordinates & $\begin{array}{l}\text { Population* } \\
(\text { million })\end{array}$ & $\begin{array}{l}\text { Population density* } \\
(\text { density/km })^{2}\end{array}$ & $\begin{array}{l}\text { No. of air quality } \\
\text { monitoring } \\
\text { (AQM) stations }\end{array}$ \\
\hline Delhi & Northcentral & $28.7041^{\circ} \mathrm{N}, 77.1025^{\circ} \mathrm{E}$ & 16.78 & 11,320 & 35 \\
Mumbai & Southwestern & $19.0760^{\circ} \mathrm{N}, 72.8777^{\circ} \mathrm{E}$ & 12.44 & 19,652 & 10 \\
Kolkata & Eastern & $22.5726^{\circ} \mathrm{N}, 88.3639^{\circ} \mathrm{E}$ & 4.49 & 24,306 & 07 \\
Chennai & Southeastern & $13.0827^{\circ} \mathrm{N}, 80.2707^{\circ} \mathrm{E}$ & 4.64 & 26,553 & 04 \\
Bengaluru & Southeastern & $12.9716^{\circ} \mathrm{N}, 77.5946^{\circ} \mathrm{E}$ & 8.44 & 4381 & 10 \\
Hyderabad & Southeastern & $17.3850^{\circ} \mathrm{N}, 78.4867^{\circ} \mathrm{E}$ & 6.73 & 18,172 & 06 \\
Jaipur & Northwestern & $26.9124^{\circ} \mathrm{N}, 75.7873^{\circ} \mathrm{E}$ & 3.07 & 595 & 03 \\
Lucknow & Northern & $26.8467^{\circ} \mathrm{N}, 80.9462^{\circ} \mathrm{E}$ & 2.81 & 1816 & 05 \\
\hline
\end{tabular}

*As per Census 2011

with meteorological parameters such as temperature and relative humidity during the COVID-19 lockdown period from March 25 to May 3, 2020, were studied and compared with the air quality data of the same period of the previous year 2019 .

\subsection{Data sources}

The data of 24 hourly concentrations of $\mathrm{PM}_{2.5}, \mathrm{PM}_{10}$, $\mathrm{NO}_{2}, \mathrm{SO}_{2}$ and 8 hourly concentrations of $\mathrm{CO}$ and $\mathrm{O}_{3}$ along with meteorological parameters such as temperature and relative humidity for eight metropolitan cities were downloaded from the online portal of CPCB, India (https://app.cpcbccr.com/ccr/\#/caaqmdashboard-all/caaqm-landing) from 80 air quality monitoring stations spread across the selected eight metropolitan cities. Data were collected for the COVID-19 lockdown period of the year 2020 from March 25 to May 3 and the same period of the previous year 2019. To compress the large data sets, average concentrations were calculated for each pollutant at all stations of each metropolitan city for each day.

\subsection{Air quality index (AQI)}

Air quality index (AQI) is a tool that represents the weighted values of individual air pollutants into a single value. AQI is computed in the subsequent two steps (CPCB 2015):

(1) Calculation of subindices (for each pollutant): It is calculated by $24 \mathrm{~h}$ average concentrations of $\mathrm{PM}_{2.5}, \mathrm{PM}_{10}, \mathrm{SO}_{2}, \mathrm{NO}_{2}, \mathrm{NH}_{3}$, and 8 hourly concentrations of $\mathrm{CO}$ and $\mathrm{O}_{3}$, and health breakpoint concentration range. For calculation, the minimum three of the above pollutants are obligatory, out of which one has to be either $\mathrm{PM}_{2.5}$ or $\mathrm{PM}_{10}$.

The subindex $\left(\mathrm{I}_{\mathrm{i}}\right)$ for a given pollutant concentration $\left(C_{\mathrm{p}}\right)$ is calculated as:

$$
\begin{aligned}
I_{\mathrm{i}}= & {\left[\left\{\left(I_{\mathrm{HI}}-I_{\mathrm{LO}}\right) /\left(B_{\mathrm{HI}}-B_{\mathrm{LO}}\right)\right\} *\left(C_{\mathrm{p}}-B_{\mathrm{LO}}\right)\right] } \\
& +I_{\mathrm{LO}}
\end{aligned}
$$

where $B_{\mathrm{HI}}=$ breakpoint concentration greater or equal to given concentration; $B_{\mathrm{LO}}=$ breakpoint concentration smaller or equal to given concentration; $I_{\mathrm{HI}}=\mathrm{AQI}$ value corresponding to $B_{\mathrm{HI}} ; I_{\mathrm{LO}}=\mathrm{AQI}$ value corresponding to $B_{\mathrm{LO}}$; and $C_{\mathrm{p}}=$ pollutant concentration.

(2) Aggregation of subindices to get an overall AQI: Maximum operator system aggregates AQI, after the calculation of subindices (Ott 1978).

$$
\mathrm{AQI}=\operatorname{Max}\left(I_{1}, I_{2}, I_{3}, \ldots, I_{n}\right)
$$

Indian air quality index (IND-AQI) is categorized into six categories to represent air quality status and its effects on human health (Table 2).

\subsection{Prominent pollutants}

The "prominent pollutant" is determined every day for all metropolitan cities to measure what pollutant is primarily responsible for the air quality deterioration and identified by the AQI system. The pollutant that 


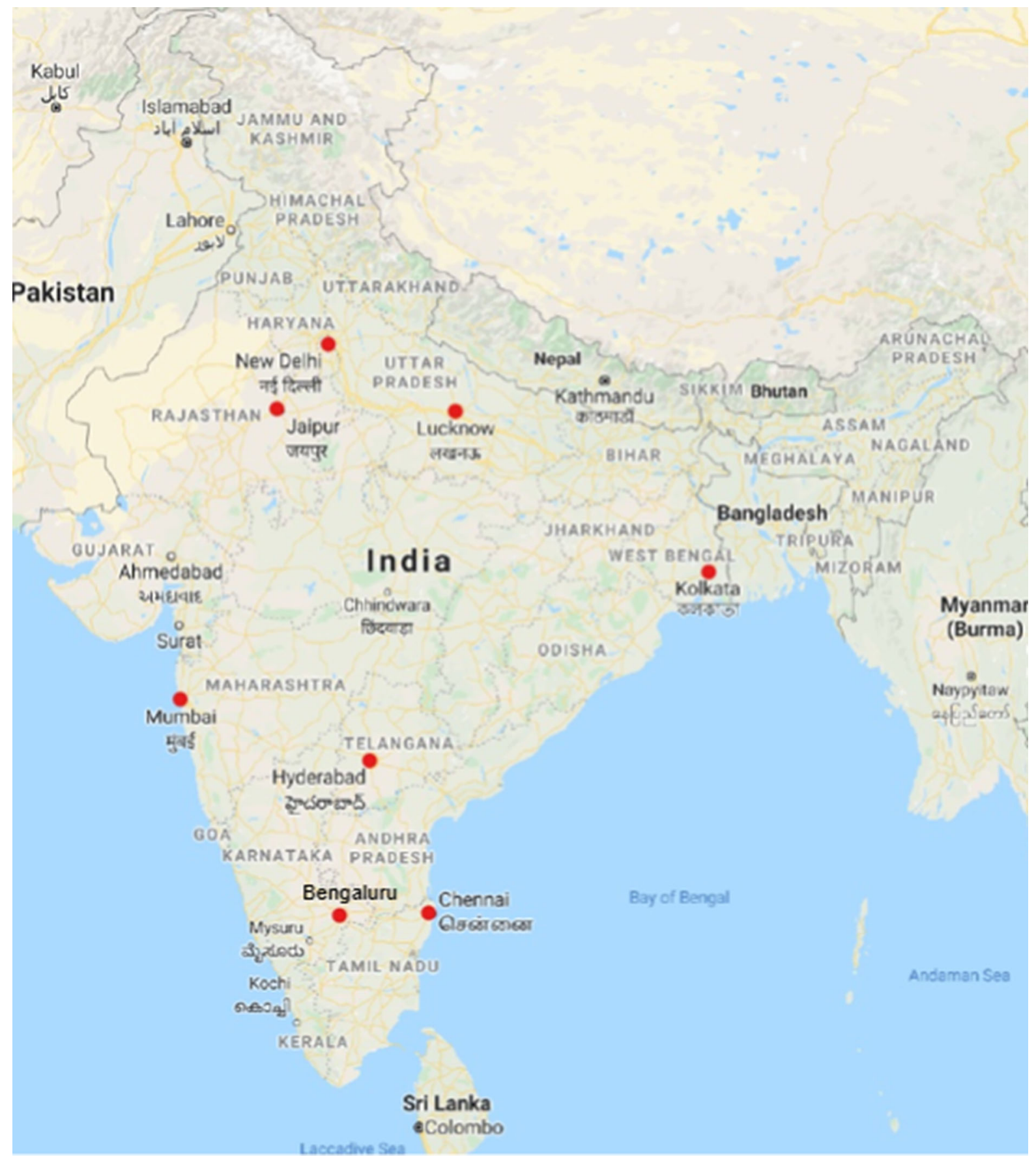

Fig. 1 Locations map of eight metropolitan cities of India. Source: https://www.google.com/maps/@24.1580341,82.7349726,5z

has maximum AQI values is identified as a prominent pollutant on that particular day (Cheng et al. 2007).
2.6 Statistical analysis

The Pearson correlation analysis was conducted among the six criteria air pollutants $\left(\mathrm{PM}_{2.5}, \mathrm{PM}_{10}\right.$, $\mathrm{CO}, \mathrm{NO}_{2}, \mathrm{SO}_{2}$, and $\mathrm{O}_{3}$ ), the meteorological parameter 
Table 2 Indian air quality index (IND-AQI) category and range

\begin{tabular}{|c|c|c|c|c|c|c|}
\hline AQI Range & $0-50$ & $51-100$ & $101-200$ & $201-300$ & $301-400$ & $401-500$ \\
\hline Category & Good & Satisfactory & Moderate & Poor & Very poor & Severe \\
\hline Color Code & & & & & & \\
\hline
\end{tabular}

(temperature and relative humidity), air quality index, and population density to investigate the interrelationship among them. The Pearson correlation coefficient $(R)$ is ranged from -1 to +1 , where $R \leq .35$ corresponds to a weak correlation, $R=.36-.67$ exhibits moderate correlation, and $R \geq .68$ represents strong correlation, and it can be positive or negative (Mason et al. 1983; Weber and Lamb 1970).

\section{Results and discussion}

\subsection{Overview of air pollutants}

The average concentrations of six criteria air pollutants monitored in eight metropolitan cities are summarized in Table 3. The average concentration of $\mathrm{PM}_{2.5}$ ranged from $17.03 \pm 8.14 \mu \mathrm{g} / \mathrm{m}^{3}$ (Chennai) to $51.66 \pm 13.05 \mu \mathrm{g} / \mathrm{m}^{3}$ (Lucknow) during the assessment period. The variation in the average concentration of $\mathrm{PM}_{2.5}$ was observed in Delhi $(-47 \%)$, Mumbai $(+1 \%), \quad$ Kolkata $(-38 \%)$, Chennai $(-48 \%)$, Bengaluru $(-52 \%)$, Hyderabad $(-23 \%)$, Jaipur $(-47 \%)$, and Lucknow $(-49 \%)$ during the COVID-19 lockdown in comparison with the same period of the previous year 2019 (Table 3; Fig. 2). The data of the average concentration of $\mathrm{PM}_{10}$ were available for six cities except for Chennai and Lucknow, ranged from $47.88 \pm 10.82 \mu \mathrm{g} / \mathrm{m}^{3}$ (Bengaluru) to $98.51 \pm 34.03 \mu \mathrm{g} / \mathrm{m}^{3}$ (Delhi) during the lockdown period. The downturn in the average concentration of $\mathrm{PM}_{10}$ was recorded in Delhi $(-57 \%)$, Mumbai $(-27 \%)$, Kolkata $(-47 \%)$, Bengaluru (-54\%), Hyderabad $(-41 \%)$, and Jaipur $(-52 \%)$ (Table 3; Fig. 2).

The decrease in the concentration of $\mathrm{PM}_{10}$ along with $\mathrm{PM}_{2.5}$ was observed in a similar pattern in Delhi, Kolkata, Bengaluru, Hyderabad, and Jaipur during the lockdown period; it indicated that a substantial fraction of $\mathrm{PM}_{10}$ is determined by $\mathrm{PM}_{2.5}$ concentration in most aforementioned cities ( $>60 \%$ ) (Wang et al. 2014; Zhang and Cao 2015) (Fig. 2). The vehicular exhaust, industrial emission, dust fallout, and construction-demolition activities are the major source of $\mathrm{PM}_{10}$ and $\mathrm{PM}_{2.5}$ pollution. The reduction in the concentration of $\mathrm{PM}_{2.5}$ and $\mathrm{PM}_{10}$ was due to a $\sim 80 \%$ drop in vehicular flux (Cyberlab 2020) and shut down of the industrial and constructional activities during the lockdown period. In Wuhan, fossil fuel combustion and vehicles on roads are the main contributors to $\mathrm{PM}_{2.5}$ (Wang et al. 2017). In Barcelona, particulate matter emission is added in the atmosphere by road transport $(+18 \%)$ and non-road transport $(+21 \%)$ (Karamchandani et al. 2017). Both these reports support the findings of our current study that transportation activities are major contributors of particulate matter (PM) in the environment, which were suspended during the lockdown period, which consequently declined the concentration of $\mathrm{PM}_{2.5}$ and $\mathrm{PM}_{10}$ in the environment. The reduction in the concentration of $\mathrm{PM}_{2.5}$ and $\mathrm{PM}_{10}$ in the present study is also supported by a similar study by Sicard et al. (2020). They also observed $36 \%$ and $49 \%$ reduction in $\mathrm{PM}_{2.5}$ and $\mathrm{PM}_{10}$ concentration, respectively, in Wuhan, China, during the lockdown period in 2020. Huang et al. (2020a, b) exhibited $9 \%$ to $34 \%$ decrease in $\mathrm{PM}_{2.5}$ concentration in China during the lockdown period in 2020.

The average concentration of $\mathrm{CO}$ ranged from $.41 \pm .09 \mathrm{mg} / \mathrm{m}^{3}$ (Kolkata) to $.99 \pm .04 \mathrm{mg} / \mathrm{m}^{3}$ (Lucknow) during the lockdown period. A decrease in the average concentration of CO in Delhi $(-43 \%)$, Mumbai $(-75 \%)$, Kolkata $(-22 \%)$, Chennai $(-32 \%)$, Bengaluru $(-28 \%)$, Hyderabad $(-23 \%)$, Jaipur (-46\%), and Lucknow $(-28 \%)$ was observed during the lockdown period as compared to the same period of 2019 (Table 3; Fig. 2). The minimum and maximum value of the average concentration of $\mathrm{NO}_{2}$ was ranged $7.92 \pm 2.53 \mu \mathrm{g} / \mathrm{m}^{3}$ (Chennai) and $21.42 \pm 4.71 \mu \mathrm{g} / \mathrm{m}^{3}$ (Hyderabad), respectively. The 
significant decline in the average concentration of $\mathrm{NO}_{2}$ was exhibited in Delhi $(-59 \%)$, Mumbai $(-59 \%)$, Kolkata $(-68 \%)$, Chennai $(-32 \%)$, Bengaluru (-64\%), Hyderabad $(-37 \%)$, Jaipur (-62\%), and Lucknow (-66\%) (Table 3; Fig. 3).

Carbon monoxide and $\mathrm{NO}_{2}$ both have also exhibited significant decline during the COVID-19 lockdown period (Fig. 2 and 3). The emission of $\mathrm{CO}$ and $\mathrm{NO}_{2}$ is primarily associated with the combustion process of fuel like gasoline and diesel in vehicles and industries. COVID-19 lockdown majorly shut down vehicular movement, industrial activities that diminished the concentration of $\mathrm{CO}$ and $\mathrm{NO}_{\mathrm{x}}$ in the environment. The transport sector (road transport: 39\% and non-road transport: $8 \%$ ) largely emits $\mathrm{NO}_{x}$ pollutants in Europe (EEA 2019). In China, industrial activities were stopped due to the COVID-19 lockdown dropped $30 \%$ and $25 \%$ of $\mathrm{NO}_{2}$ and carbon emission, respectively (Isaifan 2020). During the lockdown period, Sicard et al. (2020) noticed a similar reduction in mean $\mathrm{NO}_{2}$ concentration in urban stations of all European cities (- 57\%) and traffic stations of Wuhan (-65\%); Huang et al. (2020a, b) reported a more than $60 \%$ reduction in $\mathrm{NO}_{2}$ and $13 \%$ to $41 \%$ reduction in $\mathrm{CO}$ concentration in China; Dantas et al. (2020) reported $30.3 \%$ to $48.5 \%$ diminutions in CO concentration in Rio de Janeiro, Brazil.

The average concentration of sulfur dioxide $\left(\mathrm{SO}_{2}\right)$ ranged from $5.54 \pm 1.79 \mu \mathrm{g} / \mathrm{m}^{3}$ (Chennai) to $14.38 \pm 2.55 \mu \mathrm{g} / \mathrm{m}^{3}$ (Delhi) during the lockdown period. The variation in the average concentration of $\mathrm{SO}_{2}$ was observed in Delhi $(-32 \%)$, Mumbai $(-48 \%)$, Kolkata $(+25 \%)$, Chennai $(-22 \%)$, Bengaluru $(+9 \%)$, Hyderabad $(-9 \%)$, Jaipur $(-9 \%)$, and Lucknow (-16\%) (Table 3; Fig. 3).

The average $\mathrm{SO}_{2}$ concentration also exhibited mixed trends during the lockdown and showed a significant decline in six metropolitan cities-Delhi, Mumbai, Chennai, Hyderabad, Jaipur, and Lucknow-while there was an increase in two metropolitan cities-Kolkata and Bengaluru (Fig. 3). Burning coal is a prime source of $\mathrm{SO}_{2}$ emission in the environment, and during the lockdown period, coal power plants might not have been shut down. Therefore, it would be a possible reason for a slight variation in $\mathrm{SO}_{2}$ concentration during the lockdown as compared to the non-lockdown period of the previous year. Huang et al. (2020a, b) also observed 15-42\% diminution in $\mathrm{SO}_{2}$ concentration in China during the lockdown in 2020, which is similar to our results.

The average concentration of $\mathrm{O}_{3}$ ranged from $23.69 \pm 8.10 \mu \mathrm{g} / \mathrm{m}^{3}$ (Mumbai) to $49.55 \pm 6.85 \mu \mathrm{g} /$ $\mathrm{m}^{3}$ (Jaipur) during the lockdown period. The variation in the average concentration of $\mathrm{O}_{3}$ was observed in Delhi $(-06 \%)$, Mumbai $(-02 \%)$, Kolkata $(+63 \%)$, Chennai $(+51 \%)$, Bengaluru $(-25 \%)$, Hyderabad $(-29 \%)$, Jaipur $(-17 \%)$, and Lucknow $(-28 \%)$ (Table 3; Fig. 3).

A mixed trend is also observed in $\mathrm{O}_{3}$ concentration during the lockdown, a slight decline in six metropolitan cities (Delhi, Mumbai, Bengaluru, Hyderabad, Jaipur, and Lucknow), while there is an increase in two metropolitan cities (Kolkata, Chennai) (Fig. 3). A slight variation in $\mathrm{O}_{3}$ concentration compared to other criteria pollutants like $\mathrm{PM}_{2.5}, \mathrm{PM}_{10}, \mathrm{CO}$, and $\mathrm{NO}_{2}$ during the lockdown period might be due to three reasons: (1) Owing to the lockdown of vehicular movement and industrial activities, the reduction in NO concentration may decrease the consumption of ozone molecules (titration, $\mathrm{NO}+\mathrm{O}_{3}=\mathrm{NO}_{2}+\mathrm{O}_{2}$ ), thus increasing the $\mathrm{O}_{3}$ concentration. (2) The concentration of $\mathrm{PM}_{10}$ and $\mathrm{PM}_{2.5}$ decreases drastically during the lockdown period, which may allow extra sunlight through the atmosphere, accelerating more photochemical activities and thereby increasing ozone formation (Dang and Liao 2019; Li et al. 2019). (3) From March to August, Sun migrates in the north that causes augmentation of insolation and temperature in the northern hemisphere and leads to acceleration in ozone production (Gorai et al. 2017). Sicard et al. (2020) also reported similar results. They recorded $24 \%, 14 \%, 27 \%, 2.4 \%$, and $36 \%$ rise in $\mathrm{O}_{3}$ concentration at urban stations of Nice, Rome, Turin, Valencia, and Wuhan, respectively, during the COVID-19 lockdown in 2020.

\subsection{Overview of meteorological parameters}

The average temperature ranged from $24.27 \pm .69{ }^{\circ} \mathrm{C}$ (Bengaluru) to $31.31 \pm 1.04{ }^{\circ} \mathrm{C}$ (Mumbai) during the lockdown period. The variation in average temperature was observed in Delhi $(-7 \%)$, Mumbai $(+2 \%)$, Kolkata $(+1 \%)$, Chennai $(-3 \%)$, Bengaluru $(-10 \%)$, Hyderabad $(+3 \%)$, Jaipur $(-7 \%)$, and Lucknow $(-5 \%)$ during lockdown as compared to the same period of the previous year 2019 (Table 3; Fig. 4). The average relative humidity ranged from 
Table 3 Mean concentrations, standard deviation, maximum, minimum, and \% variation in six criteria air pollutants, temperature, relative humidity, and air quality index of selected metropolitan cities of India

\begin{tabular}{|c|c|c|c|c|c|c|c|c|c|c|c|}
\hline \multirow[t]{2}{*}{ City } & \multirow[t]{2}{*}{ Parameters } & \multirow[t]{2}{*}{ Unit } & \multicolumn{4}{|l|}{2019} & \multicolumn{4}{|l|}{2020} & \multirow{2}{*}{$\begin{array}{l}\text { Variation } \\
\%\end{array}$} \\
\hline & & & Mean & SD & Max. & Min. & Mean & SD & Max. & Min. & \\
\hline \multirow[t]{9}{*}{ Delhi } & $\mathrm{PM}_{2.5}$ & $\mu \mathrm{g} / \mathrm{m}^{3}$ & 82.42 & 24.80 & 149.27 & 23.25 & 43.60 & 12.51 & 68.55 & 23.62 & -47 \\
\hline & $\mathrm{PM}_{10}$ & $\mu \mathrm{g} / \mathrm{m}^{3}$ & 230.18 & 61.87 & 341.03 & 63.18 & 98.51 & 34.03 & 188.43 & 39.28 & -57 \\
\hline & $\mathrm{CO}$ & $\mathrm{mg} / \mathrm{m}^{3}$ & 1.34 & .30 & 1.93 & .89 & .76 & .15 & 1.04 & .52 & -43 \\
\hline & $\mathrm{NO}_{2}$ & $\mu \mathrm{g} / \mathrm{m}^{3}$ & 48.52 & 9.69 & 63.51 & 27.30 & 19.85 & 3.73 & 27.38 & 14.24 & -59 \\
\hline & $\mathrm{SO}_{2}$ & $\mu \mathrm{g} / \mathrm{m}^{3}$ & 21.29 & 4.04 & 29.09 & 11.31 & 14.38 & 2.55 & 19.29 & 10.33 & -32 \\
\hline & $\mathrm{O}_{3}$ & $\mu \mathrm{g} / \mathrm{m}^{3}$ & 47.04 & 6.07 & 61.21 & 32.97 & 44.19 & 8.87 & 60.98 & 24.06 & -6 \\
\hline & Temperature & ${ }^{\circ} \mathrm{C}$ & 28.55 & 3.46 & 33.91 & 21.63 & 26.62 & 2.71 & 31.21 & 20.92 & -7 \\
\hline & Relative humidity & $\%$ & 35.34 & 10.03 & 56.55 & 15.53 & 48.09 & 8.73 & 69.71 & 34.31 & +36 \\
\hline & Air quality index & & 210.18 & 49.72 & 302.00 & 84.00 & 103.43 & 28.74 & 180.00 & 45.00 & -51 \\
\hline \multirow[t]{9}{*}{ Mumbai } & $\mathrm{PM}_{2.5}$ & $\mu \mathrm{g} / \mathrm{m}^{3}$ & 22.72 & 7.76 & 53.91 & 12.83 & 23.04 & 3.76 & 29.55 & 14.96 & +1 \\
\hline & $\mathrm{PM}_{10}$ & $\mu \mathrm{g} / \mathrm{m}^{3}$ & 87.93 & 28.49 & 203.83 & 51.13 & 64.29 & 15.10 & 97.50 & 33.81 & -27 \\
\hline & $\mathrm{CO}$ & $\mathrm{mg} / \mathrm{m}^{3}$ & 1.77 & .13 & 2.08 & 1.43 & .44 & .11 & .75 & .32 & -75 \\
\hline & $\mathrm{NO}_{2}$ & $\mu \mathrm{g} / \mathrm{m}^{3}$ & 20.28 & 8.27 & 35.33 & 2.48 & 8.24 & 1.62 & 12.00 & 5.88 & -59 \\
\hline & $\mathrm{SO}_{2}$ & $\mu \mathrm{g} / \mathrm{m}^{3}$ & 22.74 & 5.96 & 40.86 & 1.03 & 11.76 & 3.46 & 17.33 & 5.99 & -48 \\
\hline & $\mathrm{O}_{3}$ & $\mu \mathrm{g} / \mathrm{m}^{3}$ & 24.14 & 8.74 & 49.64 & 11.69 & 23.69 & 8.10 & 48.04 & 13.19 & -2 \\
\hline & Temperature & ${ }^{\circ} \mathrm{C}$ & 30.61 & .82 & 32.30 & 29.18 & 31.31 & 1.04 & 33.87 & 29.59 & +2 \\
\hline & Relative humidity & $\%$ & 69.86 & 6.03 & 78.09 & 45.56 & 73.88 & 5.25 & 80.53 & 58.69 & +6 \\
\hline & Air quality index & & 96.90 & 14.76 & 165.00 & 80.00 & 68.30 & 13.93 & 97.00 & 40.00 & -30 \\
\hline \multirow[t]{9}{*}{ Kolkata } & $\mathrm{PM}_{2.5}$ & $\mu \mathrm{g} / \mathrm{m}^{3}$ & 43.99 & 17.05 & 99.54 & 17.05 & 27.24 & 14.64 & 59.80 & 7.73 & -38 \\
\hline & $\mathrm{PM}_{10}$ & $\mu \mathrm{g} / \mathrm{m}^{3}$ & 96.04 & 38.12 & 213.39 & 54.48 & 50.77 & 20.38 & 92.87 & 21.78 & -47 \\
\hline & $\mathrm{CO}$ & $\mathrm{mg} / \mathrm{m}^{3}$ & .52 & .11 & 1.01 & .34 & .41 & .09 & .63 & .29 & -22 \\
\hline & $\mathrm{NO}_{2}$ & $\mu \mathrm{g} / \mathrm{m}^{3}$ & 34.62 & 17.43 & 113.70 & 15.55 & 11.00 & 2.91 & 17.91 & 6.49 & -68 \\
\hline & $\mathrm{SO}_{2}$ & $\mu \mathrm{g} / \mathrm{m}^{3}$ & 6.53 & 4.54 & 18.96 & 1.77 & 8.18 & 2.08 & 12.84 & 5.20 & +25 \\
\hline & $\mathrm{O}_{3}$ & $\mu \mathrm{g} / \mathrm{m}^{3}$ & 29.43 & 10.21 & 51.99 & 13.46 & 47.88 & 12.73 & 71.42 & 27.89 & +63 \\
\hline & Temperature & ${ }^{\circ} \mathrm{C}$ & 28.30 & 1.41 & 30.79 & 25.63 & 28.56 & 1.82 & 30.91 & 23.85 & +1 \\
\hline & Relative humidity & $\%$ & 68.83 & 8.61 & 84.75 & 47.35 & 68.62 & 11.82 & 88.73 & 45.42 & -30 \\
\hline & Air quality index & & 88.63 & 43.32 & 204.00 & 27.00 & 71.43 & 29.83 & 146.00 & 32.00 & -19 \\
\hline \multirow[t]{8}{*}{ Chennai } & $\mathrm{PM}_{2.5}$ & $\mu \mathrm{g} / \mathrm{m}^{3}$ & 32.51 & 9.14 & 55.99 & 13.76 & 17.03 & 8.14 & 38.60 & 6.57 & -48 \\
\hline & $\mathrm{CO}$ & $\mathrm{mg} / \mathrm{m}^{3}$ & .90 & .09 & 1.09 & .63 & .61 & .07 & .79 & .47 & -32 \\
\hline & $\mathrm{NO}_{2}$ & $\mu \mathrm{g} / \mathrm{m}^{3}$ & 11.57 & 3.12 & 24.87 & 8.06 & 7.92 & 2.53 & 11.90 & 3.71 & -32 \\
\hline & $\mathrm{SO}_{2}$ & $\mu \mathrm{g} / \mathrm{m}^{3}$ & 7.14 & .75 & 10.79 & 6.09 & 5.54 & 1.79 & 12.51 & 4.02 & -22 \\
\hline & $\mathrm{O}_{3}$ & $\mu \mathrm{g} / \mathrm{m}^{3}$ & 24.61 & 6.36 & 41.57 & 12.33 & 37.21 & 5.00 & 51.06 & 26.16 & +51 \\
\hline & Temperature & ${ }^{\circ} \mathrm{C}$ & 30.32 & 1.04 & 33.33 & 28.50 & 29.53 & .99 & 31.12 & 27.56 & -3 \\
\hline & Relative humidity & $\%$ & 59.76 & 4.58 & 69.79 & 48.65 & 67.85 & 2.69 & 76.68 & 63.36 & +14 \\
\hline & Air quality index & & 71.48 & 19.81 & 119.00 & 44.00 & 48.50 & 6.53 & 62.00 & 39.00 & -32 \\
\hline
\end{tabular}


Table 3 continued

\begin{tabular}{|c|c|c|c|c|c|c|c|c|c|c|c|}
\hline \multirow[t]{2}{*}{ City } & \multirow[t]{2}{*}{ Parameters } & \multirow[t]{2}{*}{ Unit } & \multicolumn{4}{|l|}{2019} & \multicolumn{4}{|l|}{2020} & \multirow{2}{*}{$\begin{array}{l}\text { Variation } \\
\%\end{array}$} \\
\hline & & & Mean & SD & Max. & Min. & Mean & $\mathrm{SD}$ & Max. & Min. & \\
\hline \multirow[t]{9}{*}{ Bengaluru } & $\mathrm{PM}_{2.5}$ & $\mu \mathrm{g} / \mathrm{m}^{3}$ & 51.73 & 11.28 & 96.69 & 25.66 & 24.79 & 5.56 & 40.47 & 13.42 & -52 \\
\hline & $\mathrm{PM}_{10}$ & $\mu \mathrm{g} / \mathrm{m}^{3}$ & 104.86 & 18.05 & 150.17 & 67.28 & 47.88 & 10.82 & 68.24 & 20.17 & -54 \\
\hline & $\mathrm{CO}$ & $\mathrm{mg} / \mathrm{m}^{3}$ & 1.03 & .13 & 1.33 & .77 & .74 & .08 & .90 & .58 & -28 \\
\hline & $\mathrm{NO}_{2}$ & $\mu \mathrm{g} / \mathrm{m}^{3}$ & 33.58 & 5.08 & 47.23 & 21.56 & 11.94 & 2.02 & 17.29 & 8.99 & -64 \\
\hline & $\mathrm{SO}_{2}$ & $\mu \mathrm{g} / \mathrm{m}^{3}$ & 5.61 & 1.26 & 9.20 & 3.80 & 6.13 & 1.01 & 10.60 & 4.16 & +9 \\
\hline & $\mathrm{O}_{3}$ & $\mu \mathrm{g} / \mathrm{m}^{3}$ & 53.35 & 6.19 & 65.66 & 38.08 & 40.27 & 5.70 & 51.20 & 30.74 & -25 \\
\hline & Temperature & ${ }^{\circ} \mathrm{C}$ & 26.99 & 1.44 & 29.17 & 24.29 & 24.27 & .69 & 25.90 & 23.03 & -10 \\
\hline & Relative humidity & $\%$ & 47.40 & 9.05 & 69.57 & 33.58 & 51.85 & 11.11 & 76.69 & 33.11 & +9 \\
\hline & Air quality index & & 116.83 & 15.81 & 158.00 & 88.00 & 56.48 & 6.33 & 69.00 & 41.00 & -52 \\
\hline \multirow[t]{9}{*}{ Hyderabad } & $\mathrm{PM}_{2.5}$ & $\mu \mathrm{g} / \mathrm{m}^{3}$ & 40.01 & 8.40 & 60.61 & 24.86 & 30.95 & 7.56 & 47.85 & 16.20 & -23 \\
\hline & $\mathrm{PM}_{10}$ & $\mu \mathrm{g} / \mathrm{m}^{3}$ & 104.26 & 24.03 & 147.60 & 59.82 & 61.39 & 12.63 & 83.34 & 38.00 & -41 \\
\hline & $\mathrm{CO}$ & $\mathrm{mg} / \mathrm{m}^{3}$ & .62 & .11 & .94 & .43 & .47 & .10 & .81 & .37 & -23 \\
\hline & $\mathrm{NO}_{2}$ & $\mu \mathrm{g} / \mathrm{m}^{3}$ & 33.94 & 5.77 & 47.32 & 23.90 & 21.42 & 4.71 & 30.87 & 11.29 & -37 \\
\hline & $\mathrm{SO}_{2}$ & $\mu \mathrm{g} / \mathrm{m}^{3}$ & 6.50 & 1.78 & 10.39 & 2.85 & 5.93 & 1.73 & 10.11 & 3.77 & -9 \\
\hline & $\mathrm{O}_{3}$ & $\mu \mathrm{g} / \mathrm{m}^{3}$ & 41.60 & 6.46 & 58.10 & 29.53 & 29.56 & 5.28 & 42.08 & 20.69 & -29 \\
\hline & Temperature & ${ }^{\circ} \mathrm{C}$ & 29.37 & .62 & 30.91 & 28.18 & 30.20 & .57 & 31.17 & 28.42 & +3 \\
\hline & Relative humidity & $\%$ & 44.60 & 4.98 & 56.33 & 34.08 & 48.64 & 5.54 & 62.22 & 37.29 & +9 \\
\hline & Air quality index & & 96.50 & 17.53 & 130.00 & 62.00 & 63.10 & 11.35 & 98.00 & 41.00 & -35 \\
\hline \multirow[t]{9}{*}{ Jaipur } & $\mathrm{PM}_{2.5}$ & $\mu \mathrm{g} / \mathrm{m}^{3}$ & 51.39 & 13.14 & 89.44 & 25.53 & 27.32 & 10.18 & 51.69 & 8.40 & -47 \\
\hline & $\mathrm{PM}_{10}$ & $\mu \mathrm{g} / \mathrm{m}^{3}$ & 147.81 & 74.92 & 469.54 & 52.00 & 71.38 & 35.63 & 196.18 & 20.25 & -52 \\
\hline & $\mathrm{CO}$ & $\mathrm{mg} / \mathrm{m}^{3}$ & 1.04 & .29 & 1.73 & .73 & .56 & .08 & .77 & .40 & -46 \\
\hline & $\mathrm{NO}_{2}$ & $\mu \mathrm{g} / \mathrm{m}^{3}$ & 35.88 & 8.46 & 64.10 & 24.17 & 13.59 & 2.80 & 23.07 & 10.41 & -62 \\
\hline & $\mathrm{SO}_{2}$ & $\mu \mathrm{g} / \mathrm{m}^{3}$ & 14.10 & 2.13 & 19.85 & 10.24 & 12.84 & 2.04 & 18.53 & 8.45 & -9 \\
\hline & $\mathrm{O}_{3}$ & $\mu \mathrm{g} / \mathrm{m}^{3}$ & 59.67 & 11.70 & 81.53 & 36.59 & 49.55 & 6.85 & 65.67 & 32.00 & -17 \\
\hline & Temperature & ${ }^{\circ} \mathrm{C}$ & 31.88 & 4.05 & 36.36 & 17.48 & 29.55 & 3.21 & 34.95 & 20.88 & -7 \\
\hline & Relative humidity & $\%$ & 22.21 & 10.81 & 60.09 & 11.24 & 34.09 & 14.05 & 82.32 & 16.80 & +53 \\
\hline & Air quality index & & 135.40 & 49.83 & 364.00 & 59.00 & 79.10 & 23.71 & 168.00 & 45.00 & -42 \\
\hline \multirow[t]{8}{*}{ Lucknow } & $\mathrm{PM}_{2.5}$ & $\mu \mathrm{g} / \mathrm{m}^{3}$ & 102.17 & 33.45 & 164.34 & 45.15 & 51.66 & 13.05 & 79.96 & 29.60 & -49 \\
\hline & $\mathrm{CO}$ & $\mathrm{mg} / \mathrm{m}^{3}$ & 1.38 & .27 & 1.91 & .89 & .99 & .04 & 1.07 & .86 & -28 \\
\hline & $\mathrm{NO}_{2}$ & $\mu \mathrm{g} / \mathrm{m}^{3}$ & 43.06 & 14.90 & 85.27 & 28.24 & 14.57 & 4.85 & 25.66 & 7.54 & -66 \\
\hline & $\mathrm{SO}_{2}$ & $\mu \mathrm{g} / \mathrm{m}^{3}$ & 8.40 & 1.61 & 11.84 & 5.40 & 7.08 & 1.24 & 11.06 & 4.97 & -16 \\
\hline & $\mathrm{O}_{3}$ & $\mu \mathrm{g} / \mathrm{m}^{3}$ & 39.38 & 6.49 & 53.82 & 27.77 & 28.48 & 7.12 & 48.55 & 18.61 & -28 \\
\hline & Temperature & ${ }^{\circ} \mathrm{C}$ & 32.71 & 2.42 & 39.46 & 28.83 & 31.01 & 2.19 & 35.20 & 27.07 & $-5 \%$ \\
\hline & Relative humidity & $\%$ & 40.52 & 9.51 & 62.98 & 19.75 & 46.95 & 12.99 & 77.11 & 30.27 & +16 \\
\hline & Air quality index & & 209.40 & 61.35 & 314.00 & 90.00 & 100.40 & 34.59 & 220.00 & 58.00 & -52 \\
\hline
\end{tabular}

* Data of $\mathrm{PM}_{10}$ concentration were not available at Chennai and Lucknow

$34.09 \pm 14.05 \%$ (Jaipur) to $73.88 \pm 5.25 \%$ (Mumbai) during the lockdown period. The variation in average relative humidity was observed in Delhi $(+36 \%)$, Mumbai $(+6 \%)$, Kolkata $(-.30 \%)$, Chennai $(+14 \%)$, Bengaluru $(+9 \%)$, Hyderabad $(+9 \%)$,
Jaipur $(+53 \%)$, and Lucknow $(+16 \%)$ during lockdown as compared to the non-lockdown period of 2019 (Table 3; Fig. 4). 

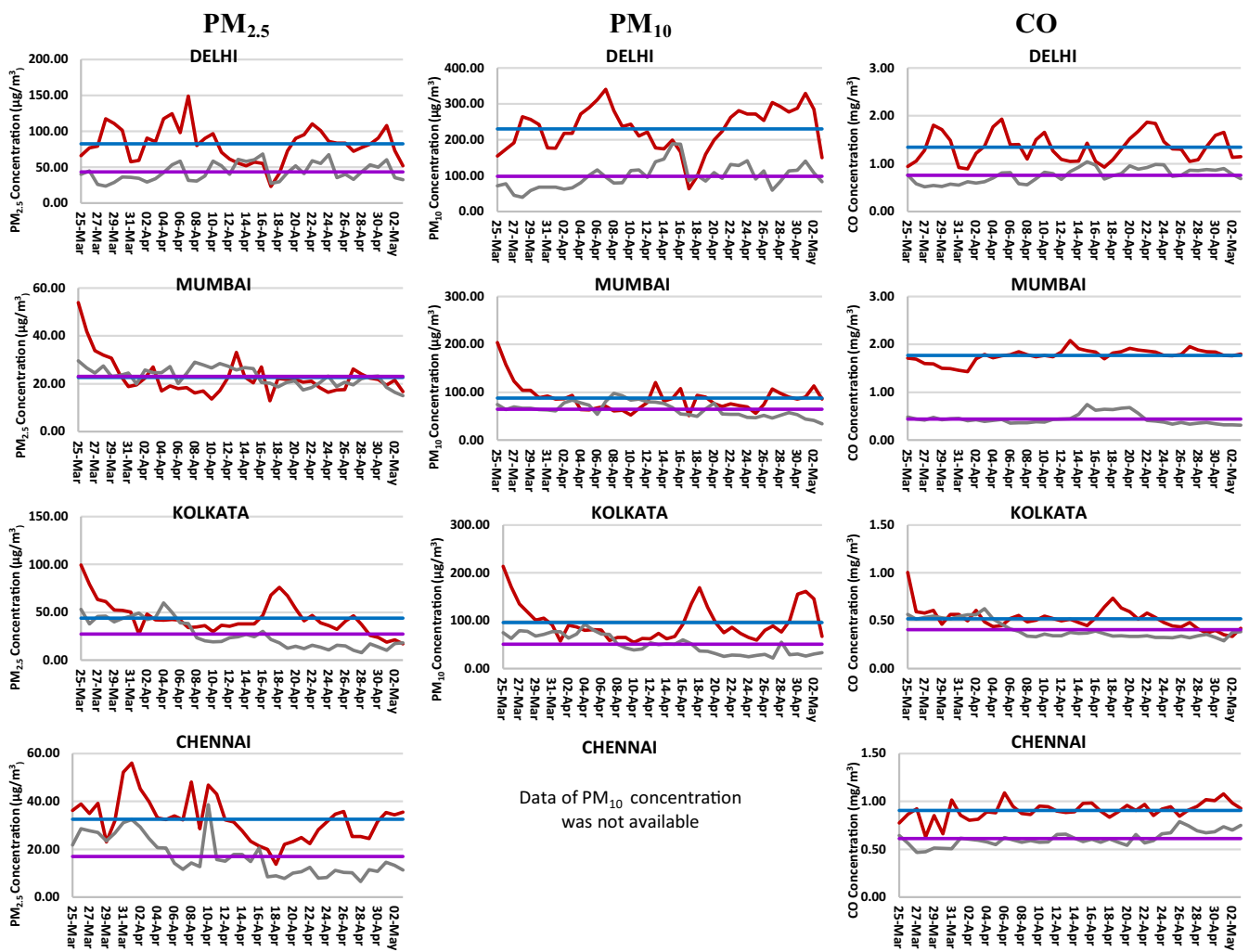

CHENNAI

CHENNAI
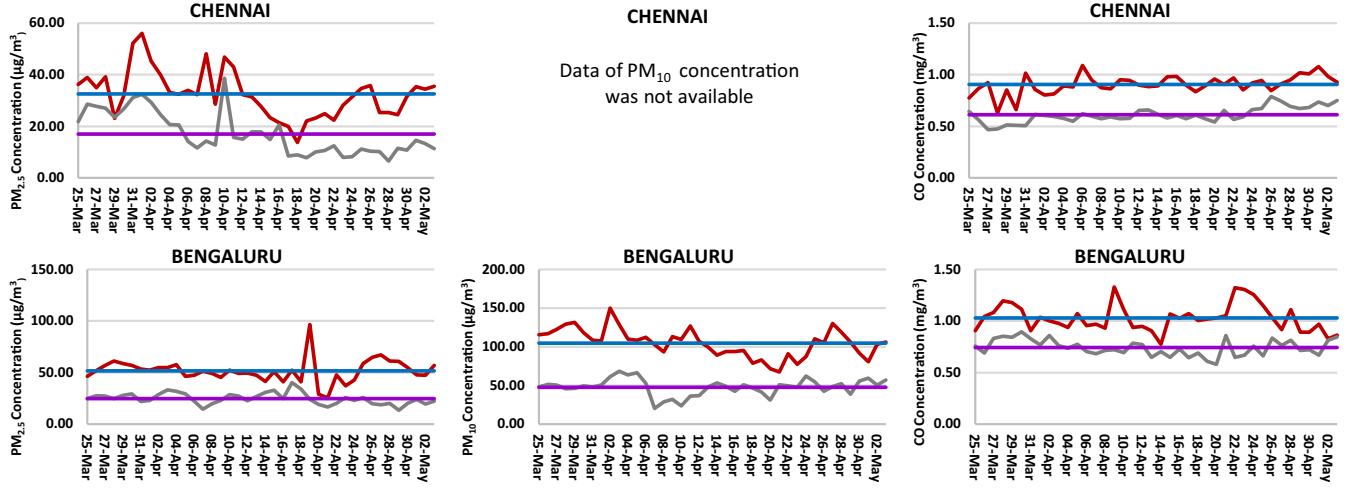

BENGALURU
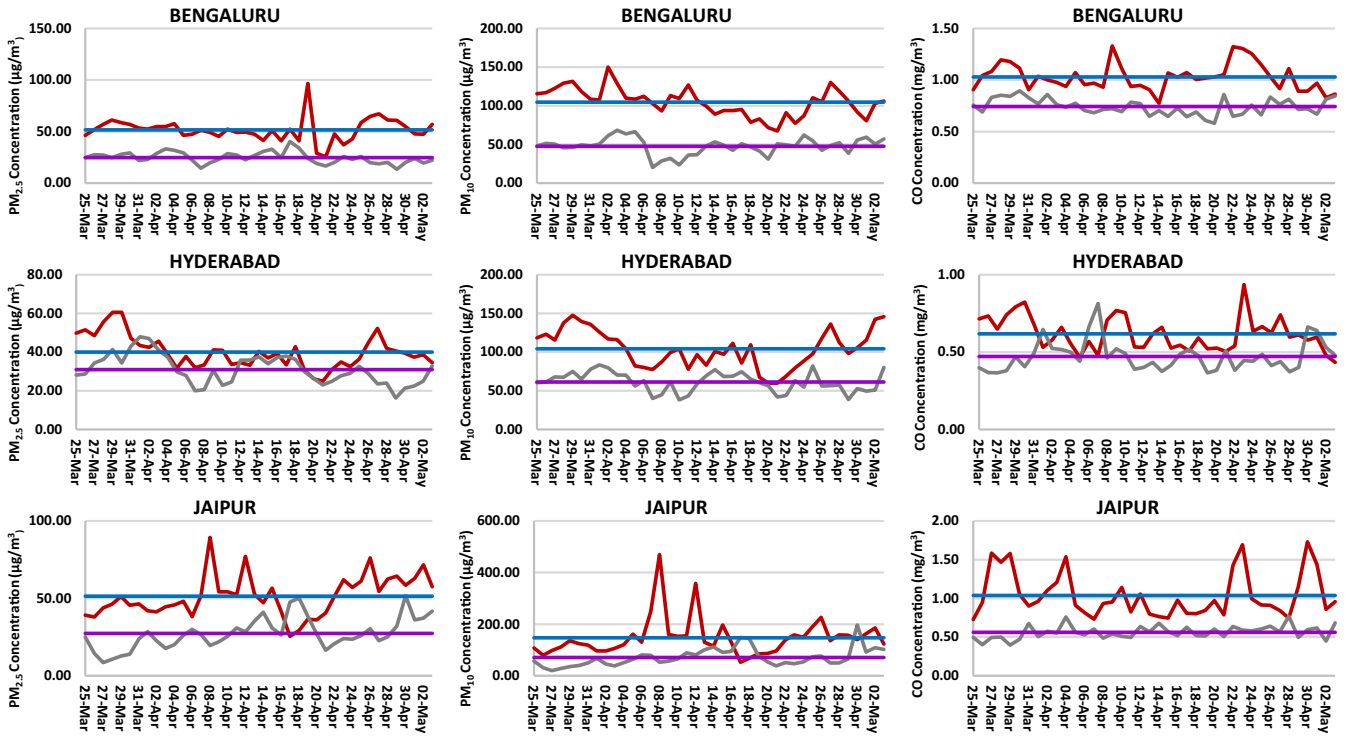

JAIPUR
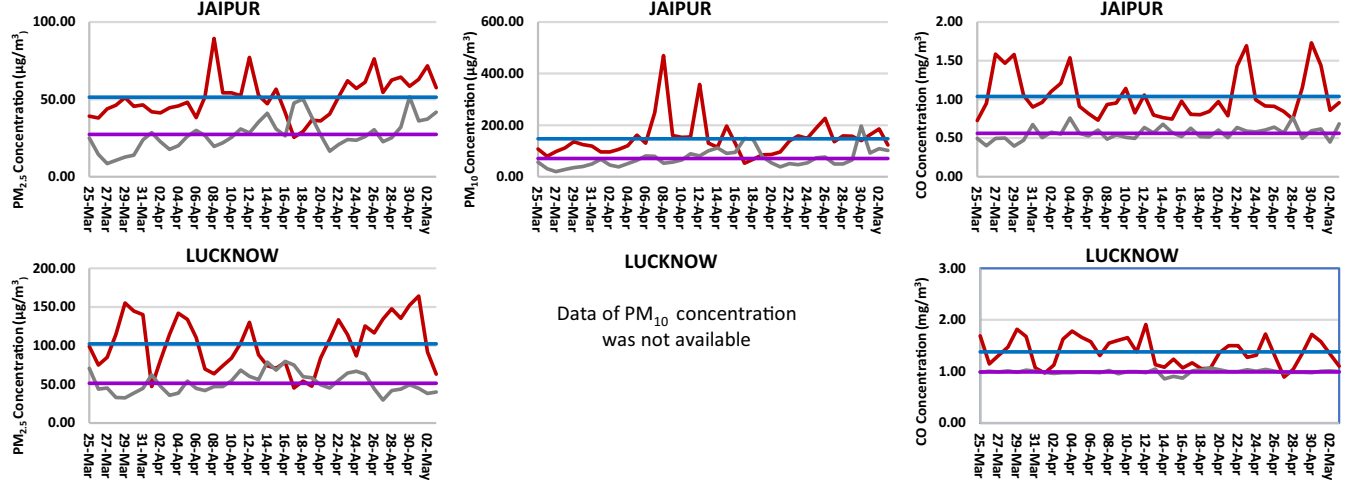

$2019 \quad 2020$ Average 2019 Average 2020 
4Fig. 2 Daily variation and average difference in mean $\mathrm{PM}_{2.5}$, $\mathrm{PM}_{10}$ and $\mathrm{CO}$ concentrations during March 25 to May 3, 2020 (COVID-19 lockdown period), and March 25 to May 3, 2019

\subsection{Air quality index}

In India, the air quality index is categorized among six categories: good (0-50), satisfactory (51-100), moderate (101-200), poor (201-300), very poor (301-400), and severe (401-500) (Table 2). The details of daily air quality index and prominent pollutants of selected eight metropolitan cities are depicted in Table 4 . The average air quality index of the eight metropolitan cities is summarized in Table 3. The average air quality index ranged from $48.50 \pm 6.53$ (Chennai) to $103.43 \pm 28.74$ (Delhi) during the lockdown period. The reduction in average air quality index was observed in Delhi $(-51 \%)$, Mumbai $(-30 \%)$, Kolkata $(-19 \%)$, Chennai $(-32 \%)$, Bengaluru $(-52 \%)$, Hyderabad $(-35 \%)$, Jaipur (-42\%), and Lucknow (-52\%) during the lockdown as compared to the same period of 2019 (Table 3). In the comparison of daily air quality index of the same period of 2019, out of eight metropolitan cities, three cities like Chennai, Bengaluru and Hyderabad exhibited a consistent reduction throughout the lockdown period, while daily air quality index of Delhi, Mumbai, Kolkata, Jaipur, and Lucknow increased on a few days (Fig. 5).

During the lockdown period, the air quality index on most of the days was observed to be good and satisfactory in all the metropolitan cities (Fig. 6) that indicated an improvement in air quality due to a reduction in vehicular and industrial emissions. The air quality index of Delhi was detected to be in a good, satisfactory, and moderate category by $2.5 \%, 52.50 \%$, and $45 \%$ days, respectively, during lockdown days, while it was satisfactory, moderate, poor, and very poor by $2.5 \%, 40 \%, 55 \%$, and $2.5 \%$ days, respectively, during the same period of 2019 . The air quality index of Mumbai was found good and satisfactory by $10 \%$ and $90 \%$ days, respectively, during the lockdown period, while it was satisfactory and poor by $87.5 \%$ and $12.5 \%$ days, respectively, in the non-lockdown period of 2019. The air quality index of Kolkata was noticed good (30\% days), satisfactory ( $47.5 \%$ days), and moderate (22.5\% days) during lockdown period, while it was good ( $10 \%$ days), satisfactory (65\% days), moderate ( $20 \%$ days), and poor (5\% days) in the same period of 2019. The air quality of Chennai was observed good (35\% days) and satisfactory $(65 \%$ days) in lockdown period, while it was good $(10 \%$ days), satisfactory (77.5\% days), and moderate (12.5\% days) in the previous year. The air quality index of Bengaluru was detected good and satisfactory by $17.5 \%$ and $82.5 \%$ days, respectively, during lockdown days, while it was satisfactory and moderate by $12.5 \%$ and $87.5 \%$ days, respectively, in the non-lockdown period of 2019. The air quality index of Hyderabad was observed to be good and satisfactory by $12.5 \%$ and $87.5 \%$ days, respectively, during lockdown days, while it was satisfactory and moderate by $57.5 \%$ and $42.5 \%$ days, respectively, on the same dates of the previous year. The air quality of Jaipur was good (5\% days), satisfactory ( $82.5 \%$ days), and moderate ( $12.5 \%$ days) in lockdown period, while it was satisfactory ( $17.5 \%$ days), moderate ( $77.5 \%$ days), poor $(2.5 \%$ days), and very poor ( $2.5 \%$ days) during the same period of the year 2019. The air quality index of Lucknow was noticed satisfactory $(62.5 \%$ days $)$, moderate (35\% days), and poor $(2.5 \%)$ during the lockdown period, while it was satisfactory (5\% days) and moderate (42.5\% days), poor (45\%), and very poor $(7.5 \%$ days) in the same period of the previous year.

The order of air quality index during lockdown for all metropolitan cities was satisfactory $>$ moderate $>$ good $>$ poor, while it was moderate $>$ satisfactory $>$ poor $>$ good $>$ very poor during the same period of the previous year 2019 .

\subsection{Prominent pollutants}

Table 4 demonstrates the prominent pollutants on all days during the lockdown in all metropolitan cities, and Fig. 7 illustrates the frequency of prominent pollutants in percentage during the study period.

Throughout the lockdown period, it was observed that ozone was the most prominent air pollutant in all metropolitan cities. The frequency of ozone as a prominent pollutant for Delhi, Mumbai, Kolkata, Chennai, Bengaluru, Hyderabad, Jaipur, and Lucknow was $75 \%, 42.50 \%, 97.50 \%, 80 \%, 80 \%, 32.50 \%$, $62.50 \%$, and $25 \%$, respectively, while it was $25 \%$, $0 \%, 7.50 \%, 10 \%, 62.50 \%, 32.50 \%, 27.50 \%$, and $2.5 \%$, respectively, during the same period of 2019 . 
$\mathrm{NO}_{2}$

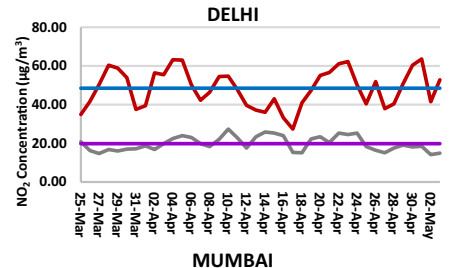

每)
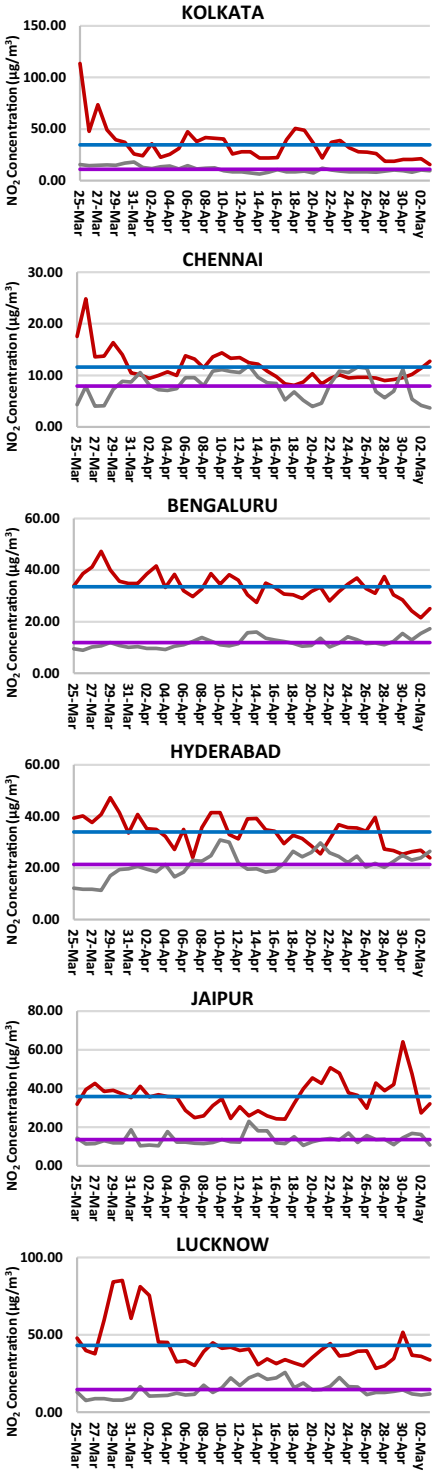

$\mathrm{SO}_{2}$
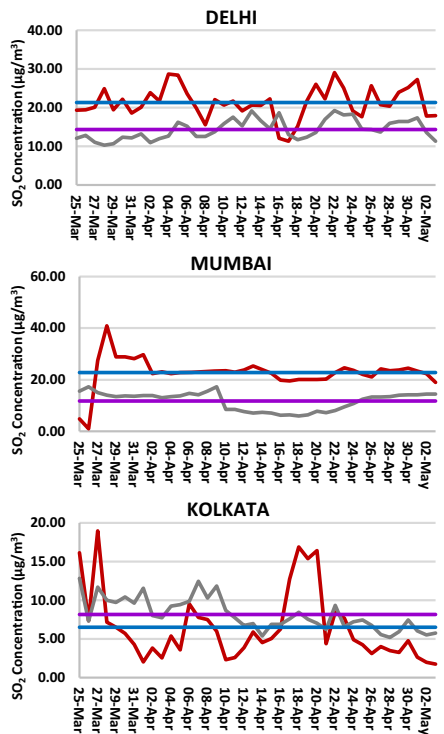
CHENNAI
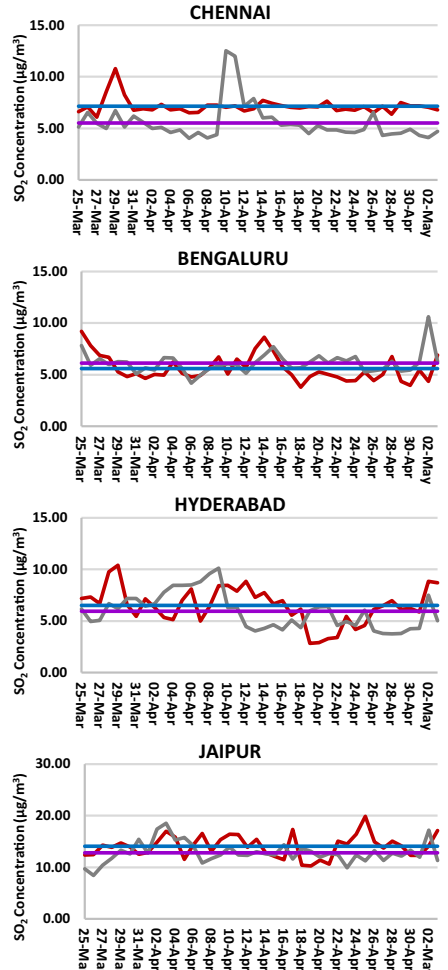
LUCKNOW

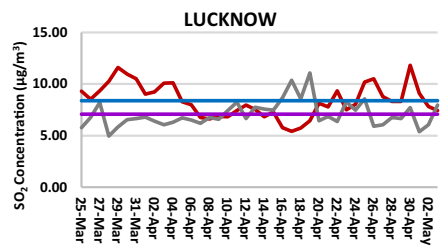

$\mathrm{O}_{3}$

DELHI
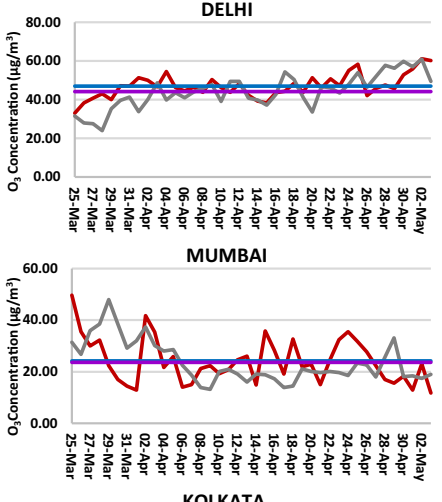

(20)

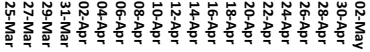

CHENNAI

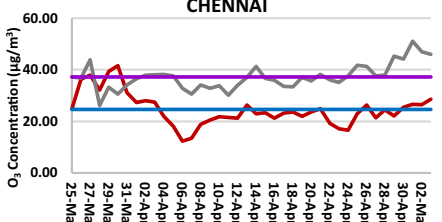

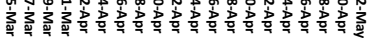
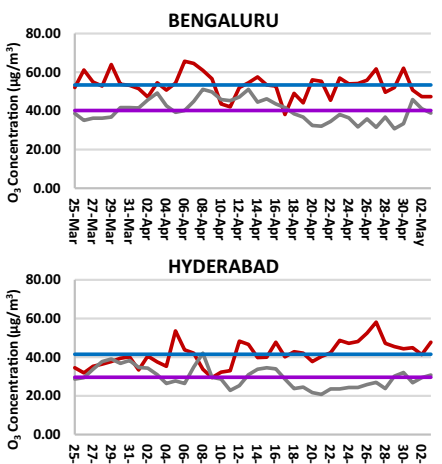

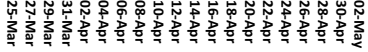

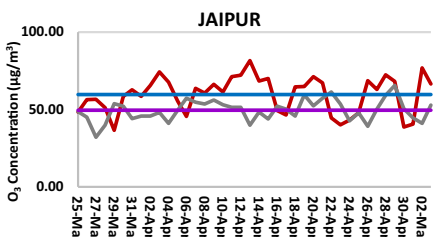
LUCKNOW

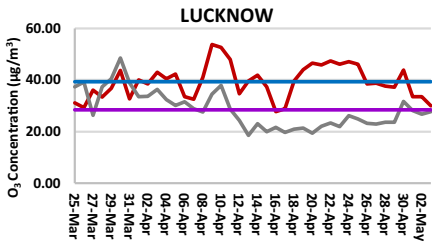

2019 Average 2019 Average 2020 
4Fig. 3 Daily variation and average difference in mean $\mathrm{NO}_{2}$, $\mathrm{SO}_{2}$, and $\mathrm{O}_{3}$ concentrations during March 25 to May 3, 2020 (COVID-19 lockdown period), and March 25 to May 3, 2019

During the lockdown period, the second and third most frequent prominent pollutants were $\mathrm{PM}_{10}$ and $\mathrm{PM}_{2.5}$, respectively, while $\mathrm{PM}_{2.5}$ and $\mathrm{PM}_{10}$ were the second and third most prominent pollutants, respectively, during 2019. The frequency of $\mathrm{PM}_{10}$ was observed in Delhi (55\%), Mumbai (100\%), Kolkata (37.5\%), Bengaluru (77.5\%), Hyderabad (92.5\%), and Jaipur $(77.5 \%)$ during the lockdown period. The frequency of $\mathrm{PM}_{2.5}$ was observed in Delhi (65\%), Mumbai (0\%), Kolkata (37.5\%), Chennai (55\%), Bengaluru (72.5\%), Hyderabad (57.5\%), Jaipur (2.5\%), and Lucknow (100\%) during the lockdown period.

Carbon monoxide was the fourth prominent pollutant during the lockdown period. The frequency of carbon monoxide for Delhi, Mumbai, Kolkata, Chennai, Bengaluru, Hyderabad, Jaipur, and Lucknow during the lockdown was $10 \%, 22.5 \%, 2.5 \%, 75 \%$, $60 \%, 5 \%, 2.5 \%$, and $17.5 \%$, respectively, while it was $0 \%, 70 \%, 2.50 \%, 85 \%, 10 \%, 0 \%, 0 \%$, and $15 \%$, respectively, during non-lockdown period of the previous year. The occurrence of $\mathrm{NO}_{2}$ and $\mathrm{SO}_{2}$ as a prominent pollutant during the lockdown as well as the non-lockdown period of 2019 was very less frequent.

The overall frequency order of prominent pollutants during lockdown was $\mathrm{O}_{3}>\mathrm{PM}_{10}>\mathrm{PM}_{2.5-}$ $>\mathrm{CO}>\mathrm{NO}_{2}>\mathrm{SO}_{2}$, while it was $\mathrm{PM}_{2.5}>\mathrm{PM}_{10}>\mathrm{CO}>\mathrm{O}_{3}>\mathrm{NO}_{2}>\mathrm{SO}_{2}$ during the same period of 2019 in all metropolitan cities. A diminution in the concentration of $\mathrm{PM}_{2.5}$ and $\mathrm{PM}_{10}$ during the lockdown period could also induce the evolution reaction of $\mathrm{O}_{3}$ by allowing more solar radiation in the troposphere (Heuss et al. 2003; Li et al. 2017; Liu et al. 2013; Murphy et al. 2007; Wolff et al. 2013) that may be a possible reason for $\mathrm{O}_{3}$ to become a prominent pollutant instead of $\mathrm{PM}_{2.5}$ and $\mathrm{PM}_{10}$.

3.5 Correlation among criteria air pollutants, temperature, relative humidity, air quality index, and population density

Pearson correlation coefficient (R) was computed among the six criteria air pollutants $\left(\mathrm{PM}_{2.5}, \mathrm{PM}_{10}, \mathrm{CO}\right.$, $\mathrm{NO}_{2}, \quad \mathrm{SO}_{2}$, and $\mathrm{O}_{3}$ ), meteorological parameters (temperature and relative humidity) and air quality index for all the eight metropolitan cities during the lockdown and the same period of the previous year 2019 (Tables 5 and 6).

During the lockdown period, $\mathrm{PM}_{2.5}$ and $\mathrm{PM}_{10}$ were strongly correlated $(\mathrm{R} \geq .68)$ in Delhi, Mumbai, Kolkata, Hyderabad, and Jaipur, while they were strongly correlated $(\mathrm{R} \geq .68)$ in Delhi, Mumbai, Hyderabad, and Jaipur during the same period of the year 2019. The strong correlation between $\mathrm{PM}_{2.5}$ and $\mathrm{PM}_{10}$ during the lockdown period and the same period of 2019 clarified that $\mathrm{PM}_{2.5}$ contributes to the formation of $\mathrm{PM}_{10}$ (Wang et al. 2014, 2017; Zhang and Cao 2015).

A strong correlation $(R \geq .68)$ between $\mathrm{PM}_{2.5}$ and $\mathrm{NO}_{2}$ in Delhi, Kolkata, and Lucknow, and $\mathrm{PM}_{10}$ and temperature in Delhi, Kolkata, and Jaipur was observed during COVID-19 lockdown period, while $\mathrm{CO}$ and $\mathrm{NO}_{2}$ in Delhi, Mumbai, Kolkata, and Hyderabad, and $\mathrm{CO}$ and $\mathrm{SO}_{2}$ in Delhi, Kolkata, and Hyderabad were strongly correlated $(R \geq .68)$ during the same period of the previous year.

Air quality index and $\mathrm{PM}_{2.5}$ were strongly correlated $(R \geq .68)$ in Delhi, Mumbai, Kolkata, Chennai, Hyderabad, Jaipur, and Lucknow during the lockdown period. It was also strongly correlated $(R \geq .68)$ in Delhi, Mumbai, Kolkata, Chennai, Hyderabad, Jaipur, and Lucknow during the same period of the year 2019. The correlation between air quality index and $\mathrm{PM}_{10}$ was found strong $(R \geq .68)$ in Delhi, Mumbai, Kolkata, Hyderabad, and Jaipur during the lockdown period and it was also strong $(R \geq .68)$ in Delhi, Mumbai, Hyderabad, and Jaipur during the same period of the previous year. The strong positive correlation between air quality index and $\mathrm{PM}_{2.5}$, and $\mathrm{AQI}$ and $\mathrm{PM}_{10}$ during the lockdown period and nonlockdown period of 2019 indicated that $\mathrm{PM}_{2.5}$ followed by $\mathrm{PM}_{10}$ dominantly influences the air quality. Yan et al. (2016) also observed that $\mathrm{PM}_{2.5}$ was chiefly degrading the air quality in Beijing and China.

During the lockdown period, the air quality index was strongly correlated $(R \geq .68)$ with CO in Delhi, Mumbai, and Kolkata. A weak correlation $(R \leq .35)$ between $\mathrm{SO}_{2}$ and $\mathrm{PM}_{2.5}$ in Mumbai, Bengaluru, Hyderabad, and Jaipur; $\mathrm{SO}_{2}$ and $\mathrm{PM}_{10}$ in Mumbai, Bengaluru, and Jaipur; $\mathrm{SO}_{2}$ and $\mathrm{CO}$ in Bengaluru, Jaipur, and Lucknow; $\mathrm{SO}_{2}$ and air quality index in Chennai, Bengaluru, and Jaipur; ozone $\left(\mathrm{O}_{3}\right)$ and $\mathrm{PM}_{2.5}$ in Delhi, Mumbai, and Jaipur; $\mathrm{O}_{3}$ and $\mathrm{PM}_{10}$ in 
Fig. 4 Daily variation and average difference in mean temperature and relative humidity during March 25 to May 3, 2020 (COVID-19 lockdown period), and March 25 to May 3, 2019
Temperature
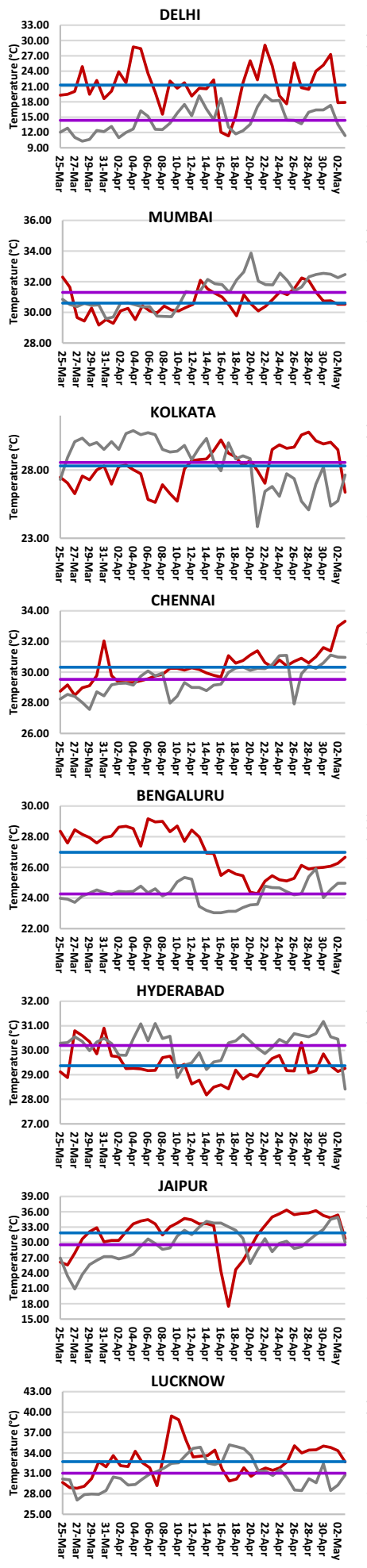

Relative Humidity
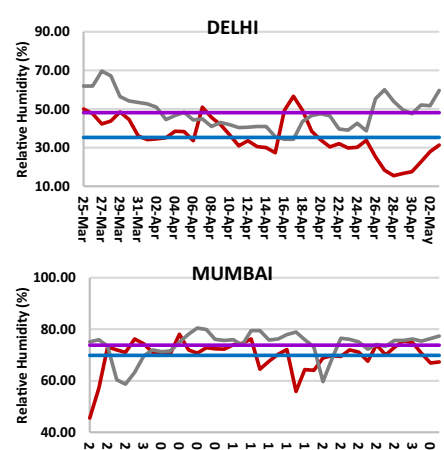

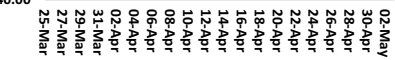
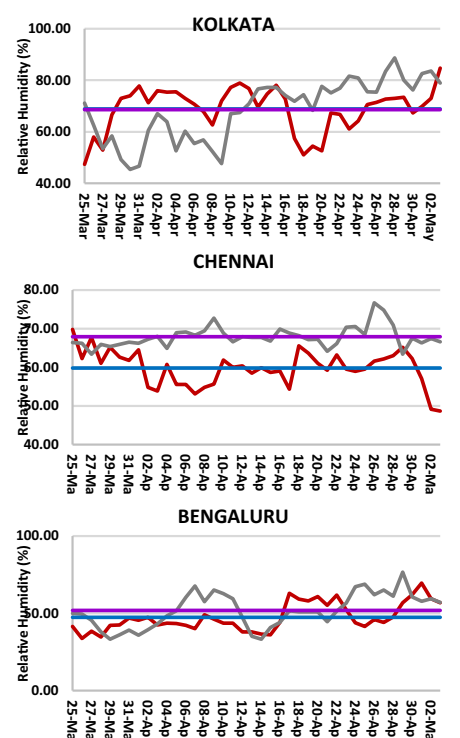
HYDERABAD
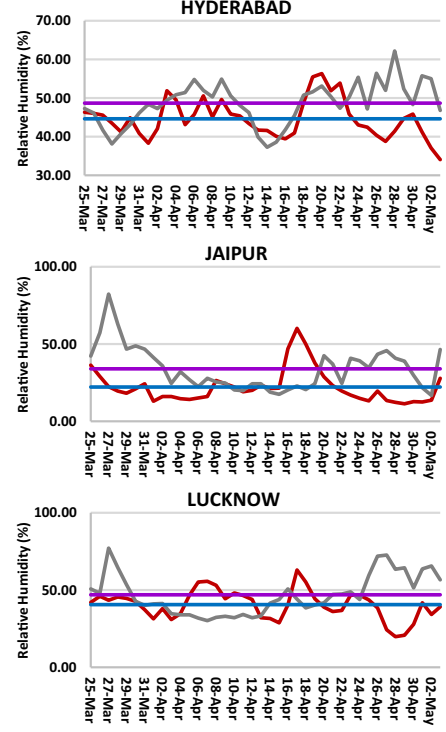

$2019 \quad 2020$ Average 2019 Average 2020 
Table 4 Air quality index and prominent pollutant during March 25 to May 3, 2020 (COVID-19 lockdown period) and March 25 to May 3, 2019

\begin{tabular}{|c|c|c|c|c|c|c|c|c|c|c|c|c|c|c|c|c|c|c|c|c|c|c|c|c|c|c|c|c|c|c|c|}
\hline & & & & & & & & & & & & & & & & & & & & & & & & & & & & & & & \\
\hline & 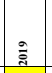 & 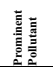 & & 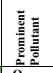 & 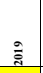 & 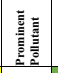 & & 离言 & $\frac{\partial}{3}$ & 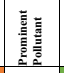 & & 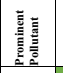 & 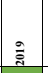 & 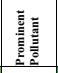 & สู้ & 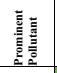 & 总 & 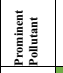 & 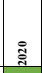 & 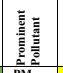 & ఫे & 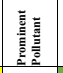 & 离 & 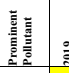 & 离衰 & 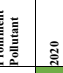 & 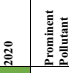 & 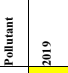 & 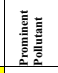 & క్ష & 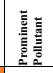 \\
\hline & & & & 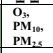 & & & & & & $\mathrm{PM}_{2 s}$ & & $1, \ldots$ & & wa.... & & $\begin{array}{l}\mathrm{O}_{12} \\
\mathrm{M}_{2 s}\end{array}$ & 98 & \begin{tabular}{|l|}
$\mathbf{P M}_{2,3}$ \\
$\mathbf{P M}_{110}$
\end{tabular} & & $\begin{array}{l}\mathrm{PM}_{2,5} \\
\mathrm{CO}^{2} \mathrm{PM}_{10}\end{array}$ & a & \begin{tabular}{|l|}
$\mathbf{P M}_{10,}$ \\
$\mathbf{P M}_{23}$ \\
\end{tabular} & $\begin{array}{l}\mathrm{PN} \\
\mathrm{PN}\end{array}$ & $\begin{array}{lll}\mathbf{P M}_{1,1,} \\
\mathrm{PM}_{2,2}\end{array}$ & 110 & $\mathrm{M}_{10}$ & $\begin{array}{l}\mathrm{PM}_{1,1} \\
\mathrm{O}_{3}\end{array}$ & \begin{tabular}{|l|l}
$I_{1,4}$ & 196
\end{tabular} & $\mathrm{PM}_{2 s}$ & 220 & \\
\hline & & & & & & & & & 104 & $1_{2,5}$ & & 2, & & 2.s, & & $i_{1,5}$ & 115 & $\begin{array}{l}\mathbf{2}_{2,2,} \\
\mathbf{y}_{10}\end{array}$ & & & 113 & \begin{tabular}{|l}
$\mathbf{P M}_{2,}$ \\
$\mathrm{PM}_{100}$
\end{tabular} & $\mathbf{P N}$ & $\mathbf{P M}_{2}$ & $s_{10}$ & $s_{10}$ & $M_{1 \ldots}$ & 194 & $\mathbf{M}_{2 s}$ & & 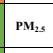 \\
\hline & & & & & & $M_{10}$ & & & \begin{tabular}{|l|}
130 \\
\end{tabular} & 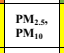 & & 1, & & & & & | & 能, & & & 104 & \begin{tabular}{|l}
$\mathbf{P M}_{10,}$ \\
$\mathbf{P M}_{23}$ \\
\end{tabular} & & $\mathrm{M}_{\mathrm{in}}$ & $s_{10}$ & $\mathrm{~s}_{\mathrm{a}}$ & 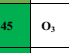 & 71 & 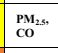 & & $\mathrm{PM}_{2}$ \\
\hline & & & & & & & & & & & & & & + & a & , & \begin{tabular}{|l|}
140 \\
\end{tabular} & \begin{tabular}{|l|l}
$\mathbf{P M}_{2,3,}$ \\
$\mathrm{PM}_{110}$
\end{tabular} & & 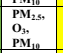 & 120 & $\begin{array}{l}\mathbf{M}_{10,} \\
\mathbf{u}_{2,5}\end{array}$ & & $\mathbf{n}_{10}$ & 103 & 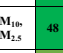 & $3_{\mathrm{M}_{\mathrm{w}}}$ & $i_{10}$ & $\mathbf{M}_{25}$ & & PI \\
\hline & & 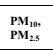 & & & & $I_{10}$ & & & 88 & $\mathbf{P M}_{2 s}$ & & 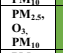 & 84 & 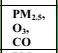 & ${ }^{46}$ & $M_{2 s}$ & 158 & \begin{tabular}{|l|l}
$\mathbf{O}_{3}$ \\
$\mathbf{P M}_{2,3}$ \\
$\mathbf{P M}_{1,10}$
\end{tabular} & & 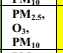 & \begin{tabular}{|l|}
128 \\
\end{tabular} & 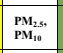 & 79 \begin{tabular}{l|l} 
PN \\
PN
\end{tabular} & 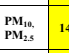 & \begin{tabular}{l|l}
144 & $\begin{array}{l}\mathrm{PM}_{2} \\
\mathrm{PM}_{2}\end{array}$ \\
\end{tabular} & \begin{tabular}{l|l}
$M_{2,25}$ & 65 \\
$M_{10}$ &
\end{tabular} & $\begin{array}{r}\mathbf{O}_{3} \\
\mathbf{P M}_{110}\end{array}$ & 284 & $\mathbf{M}_{2 s}$ & 58 & $\begin{array}{l}\text { PMI, } \\
\mathrm{CO}_{3} \\
\mathrm{O}_{3}\end{array}$ \\
\hline & & 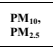 & & $\begin{array}{l}\mathrm{O}_{3,} \\
\mathrm{PM}_{2, s}\end{array}$ & & 4 & 68 & & & $\mathrm{M}_{10}$ & & $i_{10,6}$ & 76 & \begin{tabular}{|l|l|}
$\mathrm{PM}_{2, s}$ \\
0
\end{tabular} & 52 & $\mathrm{M}_{2 s}$ & 134 & 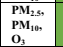 & 63 & 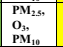 & 130 & \begin{tabular}{|l|}
$\mathrm{PM}_{2,2,}$ \\
$\mathrm{PM}_{1 \mathrm{lo}}$
\end{tabular} & $\begin{array}{l}\mathrm{PN} \\
\mathrm{PN}\end{array}$ & 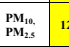 & PM $\mathrm{PM}_{\mathrm{P}_{2}}$ & $\begin{array}{l}M_{2,5} \\
M_{10}\end{array}$ & 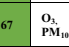 & 287 & $\mathrm{M}_{2 s}$ & 65 & $\mathrm{M}, \mathrm{x}$ \\
\hline & & & & $P$ & & $\mathbf{M}_{10}$ & & $\mathrm{PM}_{\mathrm{M}_{10}}$ & 06 & \begin{tabular}{|l}
$\mathbf{P M}_{2,3,}$ \\
$\mathrm{PM}_{110}$
\end{tabular} & & 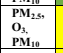 & 112 & $\mathrm{PM}_{2,5}$ & 54 & $\mathrm{PM}_{2,8}$ & 139 & 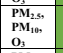 & & 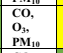 & 123 & $\begin{array}{l}\mathbf{P M}_{10,} \\
\mathbf{P M}_{25} \\
\end{array}$ & PN & 11 & $\begin{array}{l}\mathbf{P M}_{2} \\
\mathbf{P M}_{2}\end{array}$ & $\begin{array}{l}M_{2,3} \\
M_{10} \\
\end{array}$ & $\begin{array}{l}\mathbf{O}_{3} \\
\mathbf{P M}_{\mathbf{P}_{10}}\end{array}$ & 216 & $\mathrm{M}_{2 s}$ & 94 & PM \\
\hline & & & & & & & & & & & & 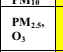 & & $\begin{array}{l}\mathbf{M}_{2, s,} \\
0\end{array}$ & 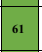 & & & 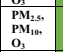 & & $\begin{array}{l}\mathrm{CO}_{10} \\
\mathrm{PM}_{2,6} \\
\mathrm{PM}_{10}\end{array}$ & & $\begin{array}{l}\mathbf{P M}_{10,} \\
\mathrm{PM}_{2,2}\end{array}$ & $\begin{array}{l}\text { PN } \\
P N \\
P N\end{array}$ & $\begin{array}{l}\mathbf{P M}_{\mathbf{P M}_{1,2}} \\
\mathrm{PM}_{2,3}\end{array}$ & $\begin{array}{l}\mathrm{PM}_{10} \\
\mathrm{PM}_{3}\end{array}$ & $\mathrm{M}_{10,0}$ & $\mathrm{P}_{3}^{\mathrm{O}_{3}}$ & 148 & 罗, & 136 & $M_{2 .}$ \\
\hline & & & 69 & & $\gamma$ & $I_{0}$ & & & & $M_{10}$ & & $\begin{array}{l}\mathbf{P M}_{2,} \\
\mathbf{O}_{3}\end{array}$ & 16 & $\begin{array}{l}\mathbf{P M}_{\mathbf{M}_{2,5}} \\
\mathrm{CO}\end{array}$ & $62 \mid$ & , & \begin{tabular}{|l|l|}
151 \\
\end{tabular} & 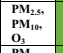 & 54 & 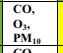 & 13 & \begin{tabular}{|l|l}
$\mathbf{P M}_{10,}$ \\
$\mathrm{PM}_{23}$
\end{tabular} & \begin{tabular}{|l|l|}
98 & PN
\end{tabular} & \begin{tabular}{l|l}
$\mathbf{P M}_{2 s}$ & 9
\end{tabular} & $\begin{array}{l}\mathbf{P M}_{\mathrm{u}_{\mathrm{C}}} \\
\mathrm{O}_{3}\end{array}$ & \begin{tabular}{|l|l}
$M_{100}$ & 65 \\
$s$ & 65
\end{tabular} & $\mathrm{o}_{3}$ & 230 & $\begin{array}{l}\mathbf{P M}_{2,} \\
\mathrm{NO}_{2}\end{array}$ & 111 & $\begin{array}{l}\mathrm{PM}_{2} \\
\mathrm{O}_{3}\end{array}$ \\
\hline & & & & 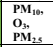 & 9 & & & $M_{10}$ & & $\mathrm{PM}_{u_{u}}$ & 109 & $\mid \begin{array}{l}\mathbf{P M}_{2,} \\
\mathbf{O}_{3}\end{array}$ & 16 & $\begin{array}{l}\mathrm{PM}_{2,2,} \\
\mathrm{Co}\end{array}$ & 56 & & 122 & 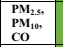 & & 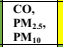 & 104 & \begin{tabular}{|l|l}
$\mathrm{PM}_{1,6, s}$ \\
$\mathrm{PM}_{2,2}$
\end{tabular} & $\mathrm{PV}$ & 11 & $\begin{array}{l}\mathrm{O}_{3} \\
\mathrm{Pu}_{2}\end{array}$ & $\mathrm{v}_{2,2}$ & 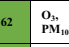 & $i_{10}$ & $M_{2 s}$ & 73 & $\begin{array}{l}\mathrm{PM}_{2} \\
\mathrm{OM}_{3}\end{array}$ \\
\hline & & & & 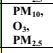 & & 0 & & & 82 & $\mathrm{PY}$ & t & \begin{tabular}{|l}
$\mathbf{P M}_{2,5}$ \\
$\mathbf{O}_{3}$
\end{tabular} & & , & 55 & & 120 & 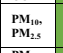 & & 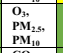 & & $\begin{array}{l}\mathbf{u}_{10,} \\
\mathbf{u}_{23}, \\
\end{array}$ & & p & s. & $\mathrm{s}_{10}$ & $s_{1,0}$ & & $\mathrm{PM}_{2 s}$ & 7 & $\begin{aligned} \mathrm{PMM}_{2} \\
\mathrm{O}_{32} \\
\mathrm{Co}\end{aligned}$ \\
\hline & & 望, & & $\mathrm{M}_{2 s}$ & & & & & 78 & 1.5 & & & 79 & $\begin{array}{l}\mathrm{P}_{2, s,} \\
\mathrm{Co}^{2}\end{array}$ & 55 & & 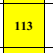 & 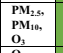 & & \begin{tabular}{|l|l}
$\mathbf{C O}_{2,}$ \\
$\mathbf{P M}_{2,0}$ \\
$\mathbf{P M}_{10}$
\end{tabular} & & $\mathrm{u}_{10}$ & 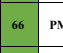 & $\mathrm{PM}_{10}$ & 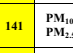 & 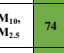 & $\begin{aligned} \mathrm{O}_{3} \\
\mathrm{PM}_{\mathrm{M}}\end{aligned}$ & 779 & $\mathrm{M}_{25}$ & 104 & $\mathbf{M}_{2}$ \\
\hline & 66 & $\mathrm{~F}$ & & $M_{25}$ & & & & & & $\mathrm{PM}_{10}$ & & $1_{12,}$ & & $\begin{array}{l}\mathrm{PM}_{2, s,} \\
\mathrm{Co}^{2}\end{array}$ & 46 & 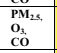 & 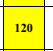 & \begin{tabular}{|l|l}
$\mathbf{O}_{3}$ \\
$\mathrm{PM}_{1,2}$ \\
$\mathrm{PM}_{2, s}$
\end{tabular} & & 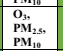 & & $\begin{array}{l}y_{26,6} \\
v_{10}\end{array}$ & PN & $\mathbf{P M}_{10}$ & 140 & $M_{10}$ & $\mathbf{M}_{\mathrm{w}}$ & 209 & $u_{2 s}$ & & $\mathrm{M}_{2}$ \\
\hline & & $\mathrm{PM}_{10}$ & & $a_{1, a,}$ & 93 & & & $\mathrm{y}$ & 66 & $0_{1}$ & & & & $\begin{array}{l}M_{2, s,} \\
0\end{array}$ & \begin{tabular}{|l|l}
40 \\
\end{tabular} & & 120 & 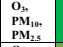 & & 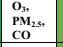 & & \begin{tabular}{|cc}
$\mathbf{P M}_{2,2}$ \\
$\mathrm{PM}_{10}$
\end{tabular} & PN & $\mathbf{P M}_{10}$ & 130 & $M_{1}$ & $\mathbf{M}_{\mathrm{n}}$ & 175 & $\mathrm{M}_{25}$ & 76 & $\begin{array}{l}\mathrm{PM}_{2} \\
\mathrm{CO}_{2}\end{array}$ \\
\hline & ${ }^{264}$ & 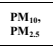 & 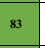 & $\mathrm{M}_{\mathrm{i}, \mathrm{o}}$ & 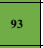 & & & & L & $\mid \begin{array}{l}\mathbf{P M}_{1,1,} \\
\mathbf{P M}_{2, s}\end{array}$ & & & & $\begin{array}{l}\mathrm{PM}_{2, s} \\
\mathrm{CO}\end{array}$ & 44 & & 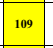 & & & $o_{3,}$ & & $\begin{array}{l}u_{1,6,} \\
u_{2,5}\end{array}$ & & $\begin{array}{l}\mathrm{PM}_{1,0,} \\
\mathrm{NO}_{2}\end{array}$ & ${ }^{P_{M}{ }_{t a}}$ & $M_{1}$ & $\mathbf{P M}_{w_{w}}$ & 136 & $\begin{array}{l}y_{2,5} \\
0, \\
b_{2}\end{array}$ & 78 & co \\
\hline & 204 & & & 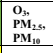 & 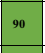 & & & & & t.s. & & & 96 & 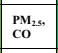 & 42 & 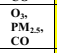 & & 1.s, & & \begin{tabular}{|l} 
\\
$\mathrm{Pu}_{2,2}$ \\
\end{tabular} & & $\begin{array}{l}M_{10,} \\
M_{2,5}\end{array}$ & & 1. & 144 & $M_{1}$ & 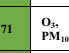 & $i_{10}$ & $\mathrm{M}_{2 s}$ & 99 & $\begin{array}{l}\mathrm{PM}_{2} \\
\mathrm{P}_{3} \\
\mathrm{O}_{3}\end{array}$ \\
\hline & 238 & $I_{10}$ & & $1_{12,2}$ & & & & & 60 & lit, & & & & 甚,s, & 62 & $\mathbf{M}_{2 s}$ & 9 & 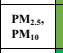 & & & & $\begin{array}{l}M_{10,} \\
M_{2 s}\end{array}$ & & & $M_{10}$ & $M_{10}$ & 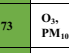 & 34 & , & 88 & $\mathrm{~B}_{3}$ \\
\hline & & & & \begin{tabular}{|l|}
$\mathrm{O}_{3,}$ \\
$\mathbf{P M}_{25}$
\end{tabular} & 8. & & & & 5 & 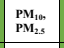 & & & 118 & $\mathrm{PM}_{2}$ & 43 & ${ }_{5,3}$ & 103 & $1,2,3$, & & $\begin{array}{l}\mathrm{Co}_{2,} \\
\mathrm{PM}_{2,3}\end{array}$ & & $\begin{array}{l}\mathrm{PM}_{10}, \\
\mathrm{PM}_{23}\end{array}$ & & & $\begin{array}{l}M_{2} \\
M_{12}\end{array}$ & 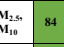 & $\mathrm{PM}_{\ldots}$ & 191 & $\mathrm{PM}_{2 s}$ & 128 & PY \\
\hline & 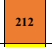 & 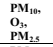 & 94 & 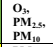 & 93 & & & & 62 & & & \begin{tabular}{|l}
$\mathrm{PM}_{1,0}$ \\
$\mathrm{O}_{3}$
\end{tabular} & & & 44 & & m & & & & & $\begin{array}{l}\mathrm{PM}_{1,0,} \\
\mathrm{PM}_{2,5}\end{array}$ & & & 64 & $M_{10}$ & $\mathbf{P M}_{\mathbf{t}_{2}}$ & & & 14 & $\mathbf{P M}_{2}$ \\
\hline Ap & 170 & 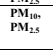 & 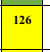 & & 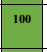 & co & & $\mathbf{m}_{10}$ & 74 & & 56 & 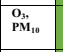 & 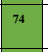 & 1,s,s, & 44 & & 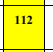 & & & & & $\begin{array}{l}\mathbf{O}_{3,} \\
\mathrm{PM}_{10}\end{array}$ & PI & 13 & 130 & $\begin{array}{l}y_{22} \\
M_{10}\end{array}$ & $\mathrm{PM}_{\mathrm{u}}$ & 228 & $\mathrm{M}_{2 s}$ & 96 & $\mathrm{PM}_{2}$ \\
\hline & & & & & & & & & & & & & & & (1) & & it & & & 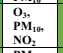 & & $\begin{array}{l}y_{1,2} \\
y_{2, s}\end{array}$ & & & $\mathrm{u}_{\mathrm{a}} \mathrm{a}$ & $\mathrm{u}_{\mathrm{a}} \mathrm{a}$ & & & & & \\
\hline & & & & & & & & & & & & 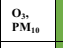 & & $\mathrm{PM}_{2}$ & 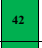 & & & & & 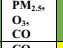 & 8 & $t_{10,0}$ & & & \begin{tabular}{|l|l}
$\mathbf{P M}_{2}$ \\
$\mathrm{PM}_{1 \mathrm{te}}$
\end{tabular} & $\begin{array}{l}\mathrm{M}_{2,5,} \\
\mathrm{u}_{10}\end{array}$ & D. & & & & \\
\hline & & & & & & & & & & & & & & $\begin{array}{c}\mathrm{CO}_{2 s} \\
\mathrm{PM}_{2 S}\end{array}$ & 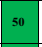 & & & & & $\begin{array}{c}\text { co } \\
\text { os } \\
p y\end{array}$ & 102 & $\mathrm{PM}_{\mathrm{tat}}$ & & $\mathrm{PM}_{10}$ & \begin{tabular}{l|l}
165 & $\mathrm{PM}$
\end{tabular} & $\mathrm{M}_{10}$ & $\mathbf{P M}_{4}$ & & & & $\mathrm{PM}_{2}$ \\
\hline & & & & & 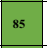 & & & & & & & & & & & & 104 & 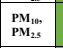 & 6 & (1.1, & & $i_{1,5}$ & & & $b_{\mathrm{v}_{10}}$ & $\mathrm{u}_{10}$ & PN & & & & \\
\hline$a_{I}$ & & & 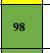 & & 9. & & 68 & & \begin{tabular}{|l|}
178 \\
\end{tabular} & & & & & & & $\begin{array}{l}{ }^{0} \\
\mathrm{c}\end{array}$ & 101 & \begin{tabular}{|l}
$\mathbf{O}_{3,}$ \\
$\mathrm{PM}_{2, s}$
\end{tabular} & & 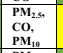 & 6 & $i_{1, s}$ & & $\mathbf{P M}_{2, s,}$ & , & $\mathrm{u}_{\mathrm{H}_{1}}$ & Py & 7 & & 118 & \\
\hline & & & & & & & & & & & & & & & & & 3 & $\begin{array}{l}\mathrm{O}_{3,3} \\
\text { co }\end{array}$ & & 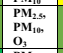 & & & & & $s_{\mathrm{u}_{\mathrm{ta}}}$ & $\mathrm{u}_{\mathrm{ta}}$ & & 90 & & & \\
\hline & & & & & & & & & & & & & & & & & & & & 25, & & $\mathrm{PM}_{\text {tot }}$ & & & 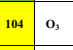 & & $o_{3}$ & & $\begin{array}{l}\mathrm{PM}_{2, s,} \\
\mathrm{CO}^{2}\end{array}$ & & \\
\hline & & & & & 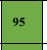 & & & & & 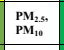 & & & & $\begin{array}{l}M_{2, s,} \\
0\end{array}$ & & & 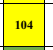 & & & is, & & 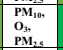 & & & , & $3_{2,}$ & 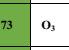 & & $1_{25}$ & 70 & $\begin{array}{l}\mathrm{M}_{2} \\
\mathbf{0}\end{array}$ \\
\hline & & & & & & & & & & & & & & 10 & & & 88 & , & & 1.25, & & & & & 126 & 80 & 0 & & ${ }_{2.5}$ & & put \\
\hline & & & & & & & & & & & & & & & & & & & & & & & & & & $\mathrm{n}_{100}$ & & 291 & & & \\
\hline & & & & & & & & & & & & & & & & & & & & & 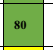 & sin & & & $\mathrm{M}_{2.2}$ & $\mathrm{M}_{2, s}$ & & & & & \\
\hline & 2 & & & & 8 & & & & & & & & & 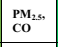 & & & & \begin{tabular}{|l|l|}
$\mathrm{PM}_{1,4}$ \\
$\mathrm{PM}_{2,2,}$ \\
$\mathrm{O}_{3}$
\end{tabular} & & 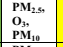 & 13 & & & & ${ }^{\mathrm{PM}_{\mathrm{ta}}}$ & $n_{1}$ & $\mathrm{O}_{3}$ & & & 126 & \\
\hline A & 2 & & & & 92 & & & & 68 & & & & & 2.s, & & & & & & & 101 & $\begin{array}{l}\mathbf{P M}_{1,0,} \\
\mathbf{P M}_{2, s}\end{array}$ & & & $\begin{array}{lll}181 & \mathrm{PM}_{\mathrm{t}}\end{array}$ & & $\mathrm{PM}$, & & & & \\
\hline A & 256 & & & $\mathrm{O}_{3}$ & 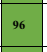 & & 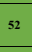 & 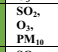 & 87 & & & & 8 & $\begin{array}{l}\mathrm{PM}_{2, s} \\
\mathrm{CO}\end{array}$ & 48 & $\begin{array}{l}\mathrm{O}_{\mathrm{s}} \\
\mathrm{CO}\end{array}$ & & & & . & 119 & & & & \begin{tabular}{l|l}
128 & '
\end{tabular} & & 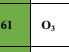 & & & & co \\
\hline & 264 & & & & 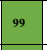 & & . & (ithe & 80 & & & & & co & & co & & & & & ${ }^{108}$ & 1.2.5 & & & $a_{10}$ & $a_{10}$ & 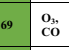 & 154 & M.2. & & \\
\hline & 248 & & & & 93 & & & & & & & & & 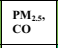 & $\left.\right|^{34}$ & со & & & & & & \begin{tabular}{|l}
$\mathbf{P M}_{1,0,}$ \\
$\mathrm{PM}_{2, s}$
\end{tabular} & & & $\mathrm{M}_{\mathrm{ita}}$ & ${ }_{11}$ & $\mathbf{P M}_{2.2}$ & & $a_{2 s}$ & 10 & \\
\hline A & 250 & & & & , & & & & & & & & & 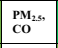 & & & & & & 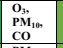 & & $\begin{array}{l}v_{1,1,} \\
u_{2, s}\end{array}$ & & & 150 & 168 & ${ }^{168}$ & & $M_{2 s}$ & & \\
\hline & 295 & & & & 88 & & & & & & & & & $\begin{array}{l}\mathrm{PM}_{2, s} \\
\mathrm{Co}\end{array}$ & & & 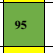 & & & & & $\begin{array}{l}\mathbf{P M}_{1,0,} \\
\mathbf{P M}_{2, s}\end{array}$ & & & 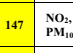 & & & & & & \\
\hline & (3) & & IIt & & 10 & & & & 27 & $\mathrm{NO}_{2}$ & & & 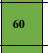 & $\mathrm{H}_{\mathrm{N}_{23}}$ & $1^{31}$ & co & 102 & 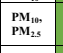 & & & 115 & 1.,5 & & & 167 & $a_{10}$ & 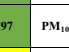 & 234 & $\mathrm{PM}_{2 s}$ & - & \\
\hline & 18 & & & & So & & & & & & & & & & & & & & & & & 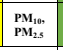 & & & 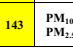 & 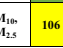 & & & & 56 & \\
\hline \multicolumn{3}{|l|}{$\overline{A 0}$} & & & & & & & & & & & & & & & & & & & & & & & & & \\
\hline
\end{tabular}




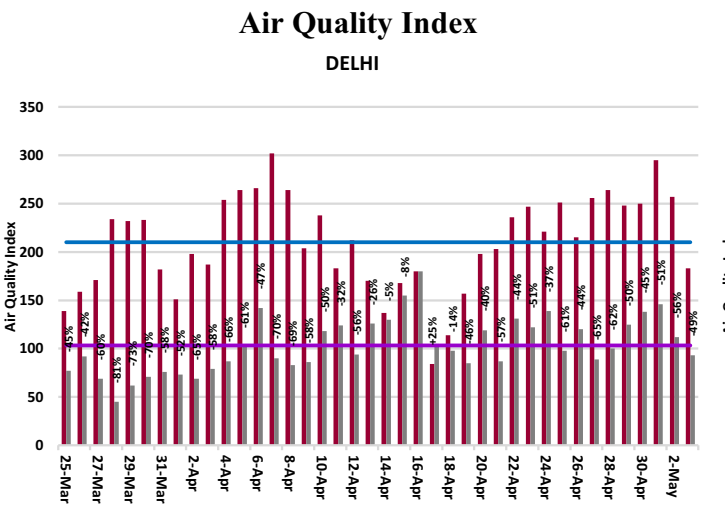

KOLKATA

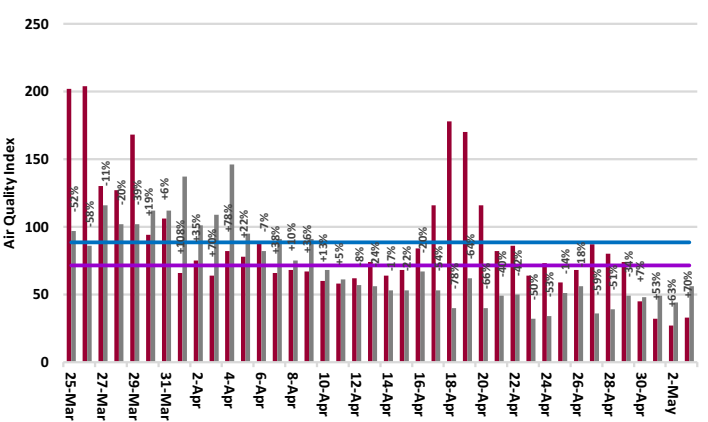

BENGALURU

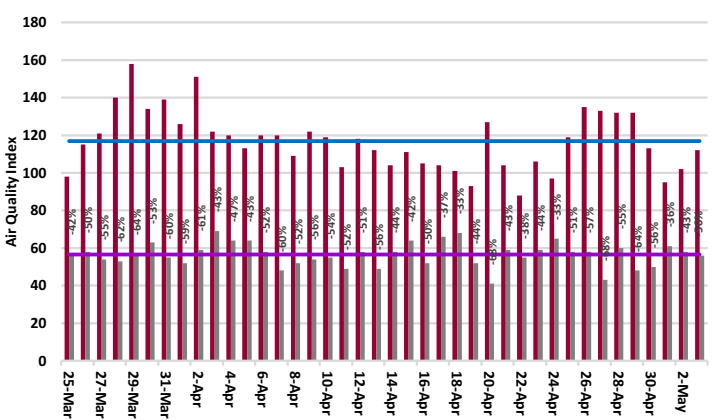

JAIPUR

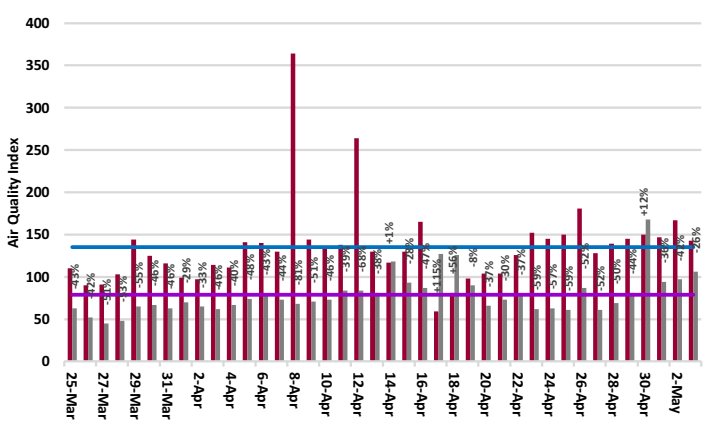

Air Quality Index

MUMBAI

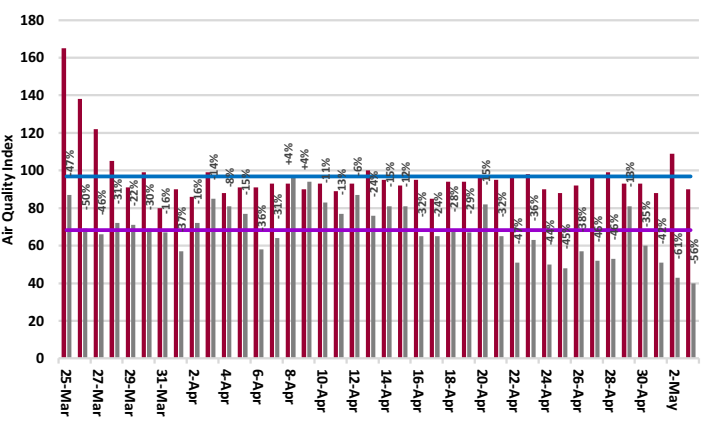

CHENNAI

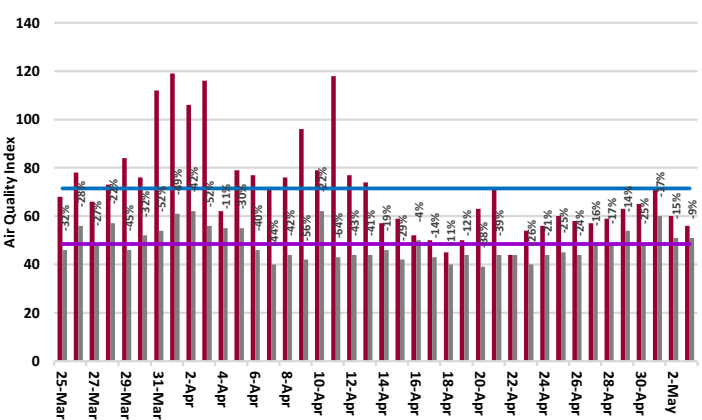

HYDERABAD

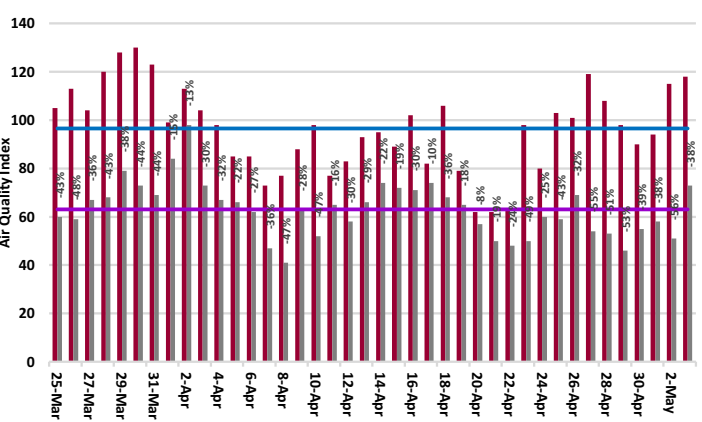

LUCKNOW

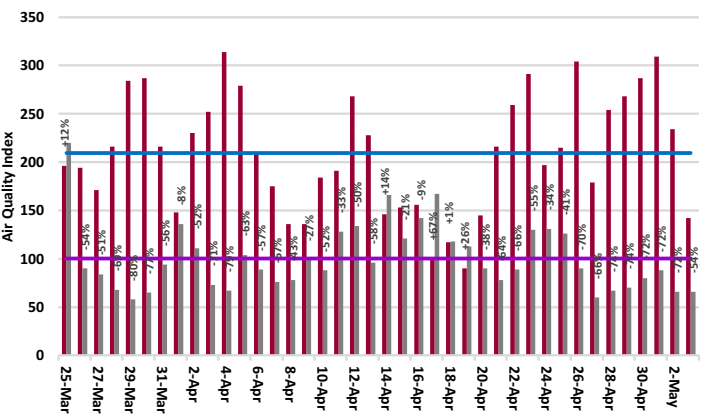

$2019 \square$ Average 2019 Average 2020 
4Fig. 5 Daily variation in percentage and average difference in air quality index during March 25 to May 3, 2020 (COVID-19 lockdown period) and March 25 to May 3, 2019

Mumbai, Kolkata, and Hyderabad; $\mathrm{O}_{3}$ and air quality index in Mumbai, Chennai, Bengaluru, Hyderabad, and Jaipur; $\mathrm{CO}$ and $\mathrm{NO}_{2}$ in Mumbai, Chennai, Hyderabad, and Jaipur; $\mathrm{CO}$ and temperature in Mumbai, Bengaluru, Hyderabad, Jaipur, and Lucknow were observed during the lockdown period.

A negative strong correlation $(R \geq-.68)$ was observed between temperature and relative humidity in Delhi, Kolkata, and Jaipur and a negative moderate correlation $(R=-.36$ to -.67$)$ between temperature and $\mathrm{PM}_{2.5}$ in Mumbai, Chennai, and Bengaluru; relative humidity and $\mathrm{PM}_{2.5}$ in Delhi, Bengaluru, Hyderabad, and Jaipur; relative humidity and $\mathrm{PM}_{10}$ in Delhi, Hyderabad, and Jaipur, and $\mathrm{O}_{3}$ and $\mathrm{NO}_{2}$ in Mumbai, Hyderabad, Jaipur, and Lucknow were observed during the lockdown period.
During the lockdown period, negative weak correlation $(R \leq-.35)$ was exhibited between $\mathrm{CO}$ and $\mathrm{PM}_{2.5}$ in Bengaluru, Hyderabad, and Lucknow; $\mathrm{CO}$ and $\mathrm{O}_{3}$ in Mumbai, Bengaluru, and Jaipur; relative humidity and $\mathrm{CO}$ in Mumbai, Bengaluru, and Jaipur; relative humidity and $\mathrm{SO}_{2}$ in Mumbai, Chennai, Bengaluru, and Lucknow; relative humidity and $\mathrm{O}_{3}$ in Chennai, Bengaluru, Jaipur, and Lucknow; air quality index and $\mathrm{NO}_{2}$ in Mumbai, Chennai, Bengaluru and Hyderabad; air quality index and temperature in Chennai, Bengaluru and Hyderabad; and air quality index and relative humidity in Mumbai, Chennai, Bengaluru, and Lucknow.

Pearson correlation coefficient (R) was also computed between air quality index and population density. During the lockdown, a negative moderate correlation $(R=-.36$ to -.67$)$ was observed between air quality index and population density, while a negative strong correlation was observed $(R \geq-.68)$ between air quality index and population density during the same period of the year 2019 .

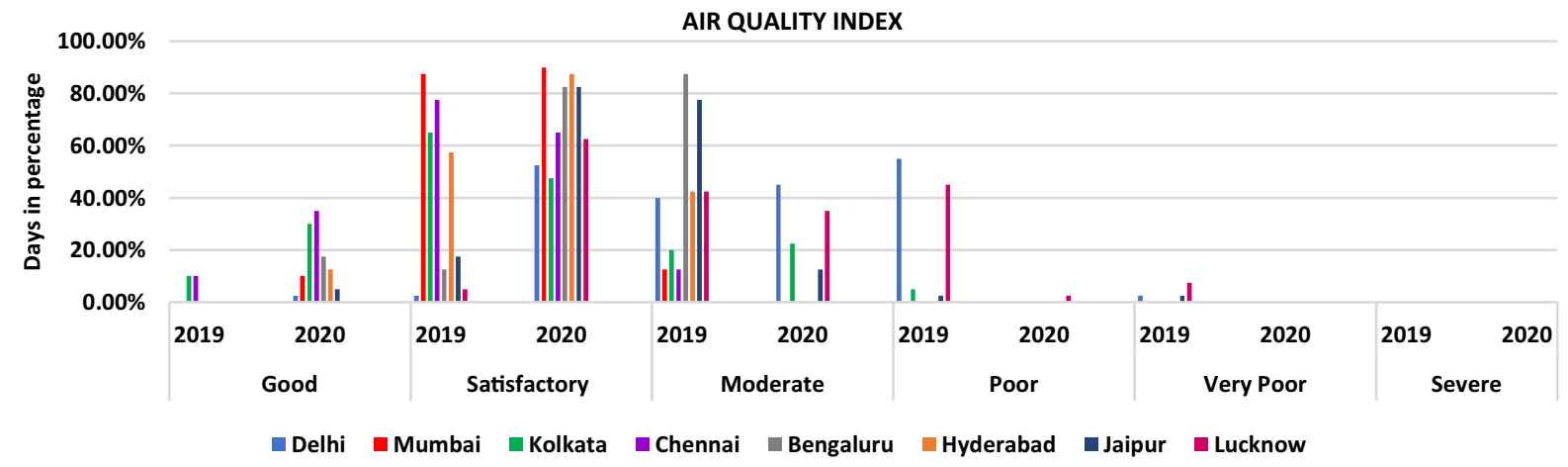

Fig. 6 Categorywise variation in air quality index during March 25 to May 3, 2020 (COVID-19 lockdown period), and March 25 to May 3, 2019

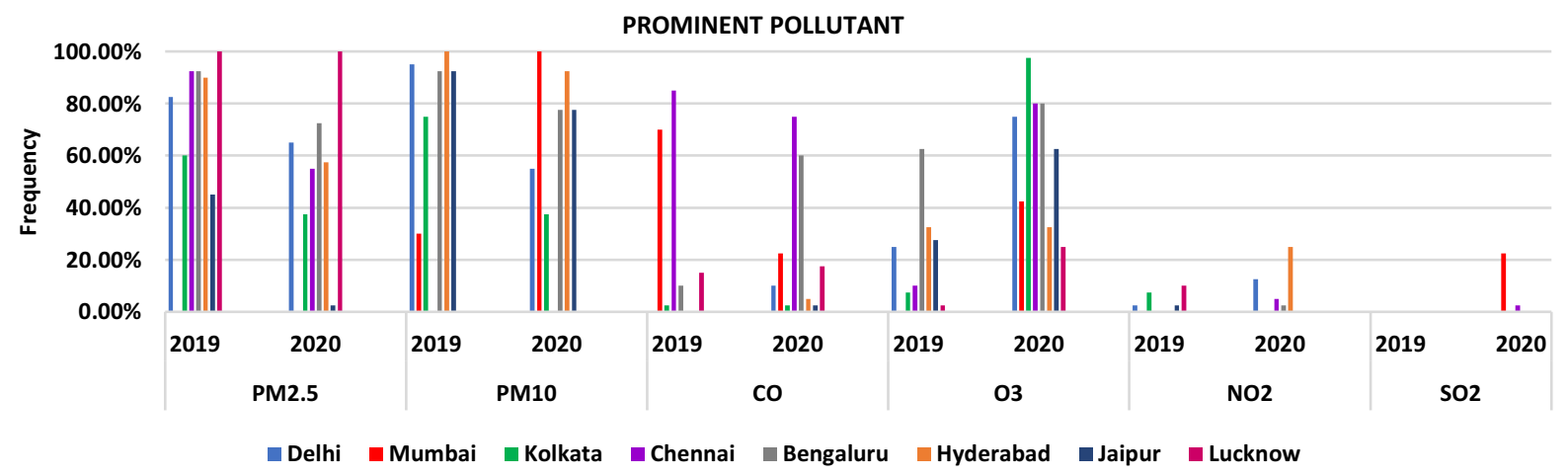

Fig. 7 Frequency of prominent pollutant during March 25 to May 3, 2020 (COVID-19 lockdown period) and March 25 to May 3, 2019 
Table 5 Correlation analysis of six criteria air pollutants, temperature, relative humidity, and air quality index of selected metropolitan cities of India during March 25 to May 3, 2020 (COVID-19 lockdown period)

\begin{tabular}{|c|c|c|c|c|c|c|c|c|c|}
\hline $\begin{array}{l}\text { Delhi } 2020 \\
\text { Parameters }\end{array}$ & $\mathrm{PM}_{2.5}$ & $\mathrm{PM}_{10}$ & $\mathrm{CO}$ & $\mathrm{NO}_{2}$ & $\mathrm{SO}_{2}$ & $\mathrm{O}_{3}$ & $\mathrm{~T}$ & $\mathrm{RH}$ & AQI \\
\hline $\mathrm{PM}_{2.5}$ & 1 & .86 & .81 & .79 & .85 & .10 & .64 & -.49 & .86 \\
\hline $\mathrm{PM}_{10}$ & & 1 & .81 & .64 & .76 & .25 & .83 & -.66 & .94 \\
\hline $\mathrm{CO}$ & & & 1 & .63 & .77 & .33 & .73 & -.48 & .82 \\
\hline $\mathrm{NO}_{2}$ & & & & 1 & .63 & -.17 & .47 & -.59 & .55 \\
\hline $\mathrm{SO}_{2}$ & & & & & 1 & .37 & .70 & -.56 & .78 \\
\hline $\mathrm{O}_{3}$ & & & & & & 1 & .55 & -.38 & .37 \\
\hline $\mathrm{T}$ & & & & & & & 1 & -.79 & .81 \\
\hline $\mathrm{RH}$ & & & & & & & & 1 & -.59 \\
\hline AQI & & & & & & & & & 1 \\
\hline $\begin{array}{l}\text { Mumbai } 2020 \\
\text { Parameters }\end{array}$ & $\mathrm{PM}_{2.5}$ & $\mathrm{PM}_{10}$ & $\mathrm{CO}$ & $\mathrm{NO}_{2}$ & $\mathrm{SO}_{2}$ & $\mathrm{O}_{3}$ & $\mathrm{~T}$ & $\mathrm{RH}$ & AQI \\
\hline $\mathrm{PM}_{2.5}$ & 1 & .83 & .06 & -.32 & .17 & .22 & -.51 & -.01 & .80 \\
\hline $\mathrm{PM}_{10}$ & & 1 & .13 & -.41 & .02 & .10 & -.52 & -.07 & .88 \\
\hline $\mathrm{CO}$ & & & 1 & .04 & -.69 & -.12 & .26 & -.18 & .32 \\
\hline $\mathrm{NO}_{2}$ & & & & 1 & -.20 & -.42 & .59 & .27 & -.23 \\
\hline $\mathrm{SO}_{2}$ & & & & & 1 & .42 & -.48 & -.08 & -.07 \\
\hline $\mathrm{O}_{3}$ & & & & & & 1 & -.36 & -.62 & .09 \\
\hline $\mathrm{T}$ & & & & & & & 1 & -.01 & -.36 \\
\hline $\mathrm{RH}$ & & & & & & & & 1 & -.09 \\
\hline $\mathrm{AQI}$ & & & & & & & & & 1 \\
\hline $\begin{array}{l}\text { Kolkata } 2020 \\
\text { Parameters }\end{array}$ & $\mathrm{PM}_{2.5}$ & $\mathrm{PM}_{10}$ & $\mathrm{CO}$ & $\mathrm{NO}_{2}$ & $\mathrm{SO}_{2}$ & $\mathrm{O}_{3}$ & $\mathrm{~T}$ & $\mathrm{RH}$ & AQI \\
\hline $\mathrm{PM}_{2.5}$ & 1 & .94 & .90 & .77 & .66 & .74 & .68 & -.72 & .92 \\
\hline $\mathrm{PM}_{10}$ & & 1 & .83 & .72 & .63 & .72 & .70 & -.72 & .88 \\
\hline $\mathrm{CO}$ & & & 1 & .80 & .51 & .64 & .52 & -.60 & .86 \\
\hline $\mathrm{NO}_{2}$ & & & & 1 & .67 & .69 & .36 & -.79 & .81 \\
\hline $\mathrm{SO}_{2}$ & & & & & 1 & .75 & .55 & -.78 & .72 \\
\hline $\mathrm{O}_{3}$ & & & & & & 1 & .70 & -.91 & .90 \\
\hline $\mathrm{T}$ & & & & & & & 1 & -.72 & .66 \\
\hline RH & & & & & & & & 1 & -.83 \\
\hline AQI & & & & & & & & & 1 \\
\hline $\begin{array}{l}\text { Chennai } 2020 \\
\text { Parameters }\end{array}$ & $\mathrm{PM}_{2.5}$ & $\mathrm{CO}$ & $\mathrm{NO}_{2}$ & $\mathrm{SO}_{2}$ & & $\mathrm{O}_{3}$ & $\mathrm{~T}$ & RH & $\mathrm{AQI}$ \\
\hline $\mathrm{PM}_{2.5}$ & 1 & -.51 & .08 & .42 & & -.21 & -.65 & -.35 & .71 \\
\hline $\mathrm{CO}$ & & 1 & .09 & -.17 & & .60 & .46 & .45 & -.04 \\
\hline $\mathrm{NO}_{2}$ & & & 1 & .40 & & -.22 & -.16 & .38 & -.11 \\
\hline $\mathrm{SO}_{2}$ & & & & 1 & & -.28 & -.41 & -.05 & .10 \\
\hline $\mathrm{O}_{3}$ & & & & & & 1 & .45 & -.11 & .23 \\
\hline $\mathrm{T}$ & & & & & & & 1 & .00 & -.16 \\
\hline $\mathrm{RH}$ & & & & & & & & 1 & -.27 \\
\hline AQI & & & & & & & & & 1 \\
\hline
\end{tabular}


Table 5 continued

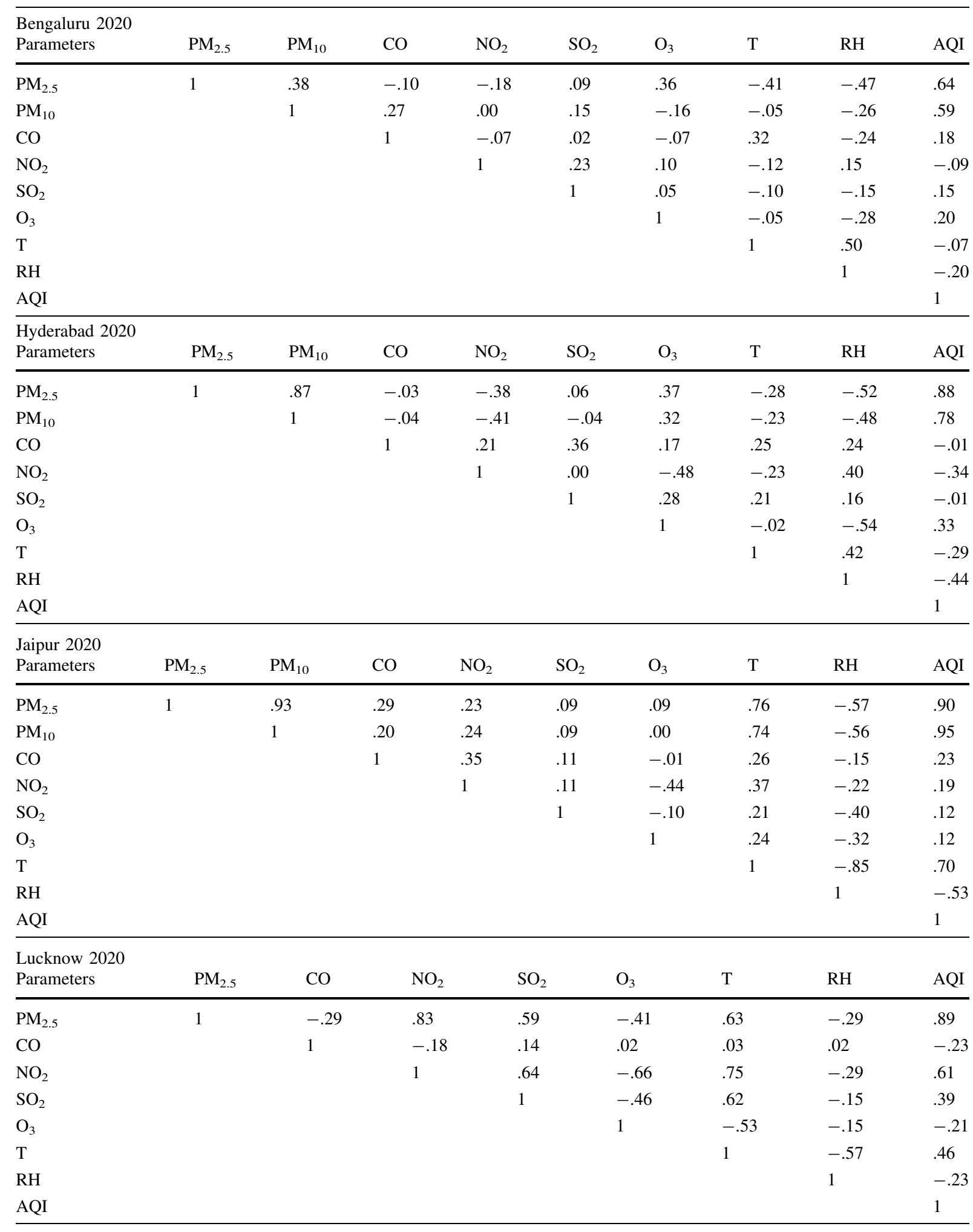

*Data of $\mathrm{PM}_{10}$ concentration were not available at Chennai and Lucknow 
Table 6 Correlation analysis of six criteria air pollutants, temperature, relative humidity, and air quality index of selected metropolitan cities of India during March 25 to May 3, 2019

\begin{tabular}{|c|c|c|c|c|c|c|c|c|c|}
\hline Delhi 2019 & & & & & & & & & \\
\hline Parameters & $\mathrm{PM}_{2.5}$ & $\mathrm{PM}_{10}$ & $\mathrm{CO}$ & $\mathrm{NO}_{2}$ & $\mathrm{SO}_{2}$ & $\mathrm{O}_{3}$ & $\mathrm{~T}$ & RH & AQI \\
\hline $\mathrm{PM}_{2.5}$ & 1 & .78 & .79 & .73 & .66 & .13 & -.01 & .25 & .77 \\
\hline $\mathrm{PM}_{10}$ & & 1 & .54 & .51 & .53 & .29 & -.45 & .67 & .97 \\
\hline $\mathrm{CO}$ & & & 1 & .89 & .72 & .18 & -.12 & .32 & .55 \\
\hline $\mathrm{NO}_{2}$ & & & & 1 & .78 & .28 & -.22 & .28 & .52 \\
\hline $\mathrm{SO}_{2}$ & & & & & 1 & .12 & -.46 & .39 & .47 \\
\hline $\mathrm{O}_{3}$ & & & & & & 1 & -.33 & .45 & .38 \\
\hline $\mathrm{T}$ & & & & & & & 1 & -.82 & -.39 \\
\hline $\mathrm{RH}$ & & & & & & & & 1 & .64 \\
\hline AQI & & & & & & & & & 1 \\
\hline $\begin{array}{l}\text { Mumbai } 2019 \\
\text { Parameters }\end{array}$ & $\mathrm{PM}_{2.5}$ & $\mathrm{PM}_{10}$ & $\mathrm{CO}$ & $\mathrm{NO}_{2}$ & $\mathrm{SO}_{2}$ & $\mathrm{O}_{3}$ & $\mathrm{~T}$ & RH & AQI \\
\hline $\mathrm{PM}_{2.5}$ & 1 & .94 & -.08 & .24 & -.37 & .55 & -.56 & .36 & .88 \\
\hline $\mathrm{PM}_{10}$ & & 1 & -.09 & .18 & -.43 & .48 & -.59 & .40 & .86 \\
\hline $\mathrm{CO}$ & & & 1 & .81 & -.26 & .02 & -.08 & .62 & -.05 \\
\hline $\mathrm{NO}_{2}$ & & & & 1 & -.50 & .31 & -.43 & .57 & .27 \\
\hline $\mathrm{SO}_{2}$ & & & & & 1 & -.34 & .67 & -.50 & -.56 \\
\hline $\mathrm{O}_{3}$ & & & & & & 1 & -.43 & .28 & .54 \\
\hline $\mathrm{T}$ & & & & & & & 1 & -.44 & -.65 \\
\hline RH & & & & & & & & 1 & .35 \\
\hline $\mathrm{AQI}$ & & & & & & & & & 1 \\
\hline $\begin{array}{l}\text { Kolkata } 2019 \\
\text { Parameters }\end{array}$ & $\mathrm{PM}_{2.5}$ & $\mathrm{PM}_{10}$ & $\mathrm{CO}$ & $\mathrm{NO}_{2}$ & $\mathrm{SO}_{2}$ & $\mathrm{O}_{3}$ & $\mathrm{~T}$ & $\mathrm{RH}$ & AQI \\
\hline $\mathrm{PM}_{2.5}$ & 1 & .61 & .86 & .78 & .75 & .53 & -.14 & -.71 & .93 \\
\hline $\mathrm{PM}_{10}$ & & 1 & .47 & .55 & .52 & .23 & .13 & -.63 & .60 \\
\hline $\mathrm{CO}$ & & & 1 & .84 & .71 & .58 & -.31 & -.66 & .74 \\
\hline $\mathrm{NO}_{2}$ & & & & 1 & .74 & .55 & -.42 & -.71 & .71 \\
\hline $\mathrm{SO}_{2}$ & & & & & 1 & .74 & -.20 & -.87 & .71 \\
\hline $\mathrm{O}_{3}$ & & & & & & 1 & -.45 & -.73 & .50 \\
\hline $\mathrm{T}$ & & & & & & & 1 & .04 & -.19 \\
\hline $\mathrm{RH}$ & & & & & & & & 1 & -.69 \\
\hline AQI & & & & & & & & & 1 \\
\hline $\begin{array}{l}\text { Chennai } 2019 \\
\text { Parameters }\end{array}$ & $\mathrm{PM}_{2.5}$ & $\mathrm{CO}$ & $\mathrm{NO}_{2}$ & $\mathrm{SO}_{2}$ & $\mathrm{O}_{3}$ & $\mathrm{~T}$ & $\mathrm{RH}$ & AQI & \\
\hline $\mathrm{PM}_{2.5}$ & 1 & -.10 & .27 & -.18 & .17 & -.12 & -.12 & .73 & \\
\hline $\mathrm{CO}$ & & 1 & -.24 & -.33 & -.43 & .45 & -.19 & -.13 & \\
\hline $\mathrm{NO}_{2}$ & & & 1 & .21 & .40 & -.41 & .15 & .23 & \\
\hline $\mathrm{SO}_{2}$ & & & & 1 & .45 & -.16 & .12 & .12 & \\
\hline $\mathrm{O}_{3}$ & & & & & 1 & -.12 & .31 & .23 & \\
\hline $\mathrm{T}$ & & & & & & 1 & -.39 & -.25 & \\
\hline $\mathrm{RH}$ & & & & & & & 1 & -.09 & \\
\hline AQI & & & & & & & & 1 & \\
\hline
\end{tabular}


Table 6 continued

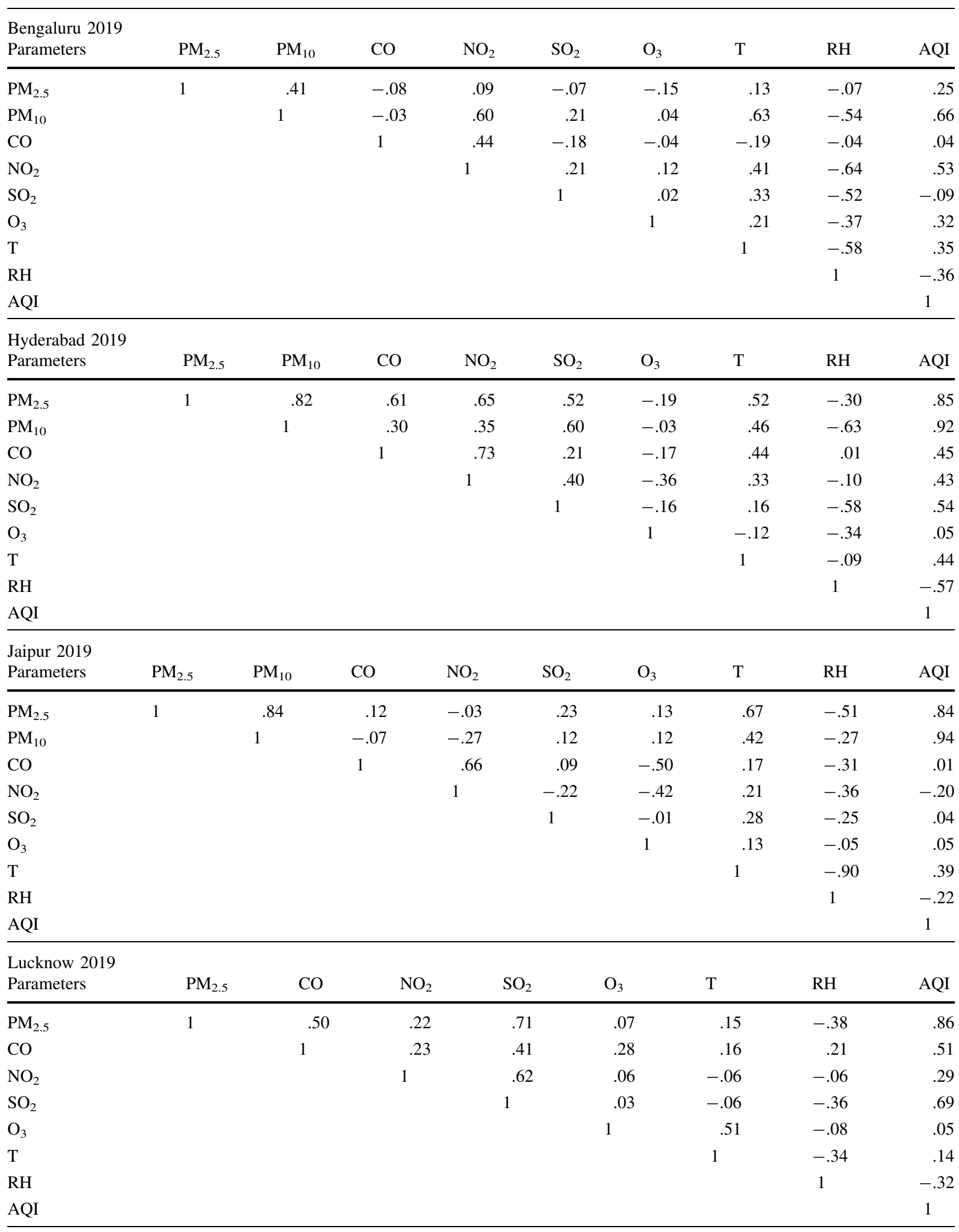

*Data of $\mathrm{PM}_{10}$ concentration were not available at Chennai and Lucknow 


\section{Conclusion}

The COVID-19 lockdown saved tens of thousands lives and controlled the transmission of SARS-CoV-2 primarily in many of the countries. Subsequently, it also restored the air quality of the world in a very impressive way. Major Indian metropolitan cities also re-established the degraded air quality during the COVID-19 lockdown period. It is concluded that out of six criteria pollutants, the concentration of four criteria pollutants like $\mathrm{PM}_{2.5}, \mathrm{PM}_{10}, \mathrm{CO}$, and $\mathrm{NO}_{2}$ drastically decreased, while the concentration of $\mathrm{SO}_{2}$ and $\mathrm{O}_{3}$ declined slightly in most of the metropolitan cities during the COVID-19 lockdown period. The order of air quality index during lockdown for all metropolitan cities was satisfactory $>$ moderate $>$ good $>$ poor, while it was moderate $>$ satisfactory $>$ poor $>$ good $>$ very poor during the previous year. It is concluded that the frequency order of prominent pollutants during lockdown was $\mathrm{O}_{3}$ $>\mathrm{PM}_{10}>\mathrm{PM}_{2.5}>\mathrm{CO}>\mathrm{NO}_{2}>\mathrm{SO}_{2}$, while it was $\mathrm{PM}_{2.5}>\mathrm{PM}_{10}>\mathrm{CO}>\mathrm{O}_{3}>\mathrm{NO}_{2}>\mathrm{SO}_{2}$ during the same period of 2019 in all metropolitan cities. Overall air quality was improved during the lockdown period in Indian metropolitan cities. Further, based on the results of this study it is suggested that India should implement the lockdown once in a month to repair the damage of the air quality caused by heavy vehicular and industrial emissions.

Acknowledgements The authors are thankful to Central Pollution Control Board, Ministry of Environment, Forest and Climate Change (MoEFCC), Government of India, for air quality data. DSR thanks Science and Engineering Research Board, Department of Science and Technology (DST), New Delhi, for a core research grant (CRG/2019/006919), and BS thanks DST for the INSPIRE Fellowship (DST/INSPIRE/03/ 2018/003129).

Authors' contribution DSR contributed to conceptualization, formal analysis, funding acquisition, methodology, investigation, and writing the original draft; $\mathrm{CN}$ and TK took part in data curation; BS carried out data curation and funding acquisition; CSC performed formal analysis and validation; RP conducted formal analysis; Harish contributed to writing, reviewing, and editing; RKK wrote the original draft; GN contributed to writing, reviewing, and editing; and LSJ contributed to formal analysis, writing, reviewing, and editing.

\section{Compliance with ethical standards}

Conflict of interest The authors declare that they have no known competing financial interests or personal relationships that could have appeared to influence the work reported in this paper.

\section{References}

Akyol, S., Erdogan, S., Idiz, N., Celik, S., Kaya, M., Ucar, F., et al. (2014). The role of reactive oxygen species and oxidative stress in carbon monoxide toxicity: An in-depth analysis. Redox Report, 19, 180-189. https://doi.org/10. 1179/1351000214Y.0000000094.

Bortnick, S. M., Coutant, B. W., \& Eberly, S. I. (2002). Using continuous $\mathrm{PM}_{2.5}$ monitoring data to report an air quality index. Journal of the Air \& Waste Management Association, 52, 104-112. https://doi.org/10.1080/10473289.2002. 10470763.

Burke, R. M., Midgley, C. M., Dratch, A., Fenstersheib, M., Haupt, T., Holshue, M., et al. (2020). Active monitoring of persons exposed to patients with confirmed COVID-19 United States. Morbidity and Mortality Weekly Report, 1, 1 . mm6909e1externalicon.

Cadotte, M. (2020). Early Evidence that COVID-19 Government Policies Reduce Urban Air Pollution. https://doi.org/ 10.31223/osf.io/nhgj3.

Chan, J., Yuan, S., Kok, K., Kai Wang-To, K., Chu, H., Yang, J., et al. (2020). A familial cluster of pneumonia associated with the 2019 novel coronavirus indicating person-to-person transmission: A study of as family cluster. Lancet. https://doi.org/10.1016/S0140-6736(20)30154-9.

Chauhan, A., \& Singh, R. P. (2020). Decline in $\mathrm{PM}_{25}$ concentrations over major cities around the world associated with COVID-19. Environmental Research, 187, 109634. https:// doi.org/10.1016/j.envres.2020.109634.

Chen, T. M., Gokhale, J., Shofer, S., \& Kuschner, W. G. (2007). Outdoor air pollution: Nitrogen dioxide, sulfur dioxide, and carbon monoxide health effects. American Journal of the Medical Sciences, 333, 249-256. https://doi.org/10.1097/ MAJ.0b013e31803b900f.

Cheng, W. L., Chen, Y. S., Zhang, J., Lyons, T. J., Pai, J. L., \& Chang, S. H. (2007). Comparison of the revised air quality index with the PSI and AQI indices. Science of the Total Environment, 382, 191-198. https://doi.org/10.1016/j. scitotenv.2007.04.036.

Cohen, A. J., Brauer, M., Burnett, R., Anderson, H. R., Frostad, J., Estep, K., et al. (2017). Estimates and 25-year trends of the global burden of disease attributable to ambient air pollution: An analysis of data from the global burden of diseases study 2015. Lancet, 389, 1907-1918. https://doi. org/10.1016/S0140-6736(17)30505-6.

CPCB. (2015). National Air Quality Index (pp. 1-55). New Delhi: Central Pollution Control Board.

Cyberlab. (2020). Dados de contagem veicular. https://twitter. com/cyberlabsai?ref_sr=twsrc\%5Egoogle\%7Ctwcamp\% 5Eserp\%7Ctwgr\%5Eauthorc. Accessed April 10, 2020.

Dang, R., \& Liao, H. (2019). Radiative forcing and health impact of aerosols and ozone in China as the consequence of clean air actions over 2012-2017. Geophysical Research Letters, 46, 12511-12519. https://doi.org/10.1029/ 2019GL084605. 
Dantas, G., Siciliano, B., Franca, B. B., da Silva, C. M., \& Arbilla, G. (2020). The impact of COVID-19 partial lockdown on the air quality of the city of Rio de Janeiro, Brazil. Science of the Total Environment, 729, 139085. https://doi.org/10.1016/j.scitotenv.2020.13.

Donkelaar, A., Martin, R. V., Brauer, M., Hsu, N. C., Kahn, R. A., Levy, R. C., et al. (2016). Global estimates of fine particulate matter using a combined geophysical-statistical method with information from satellites, models, and monitors. Environmental Science Technology, 50, 3762-3772. https://doi.org/10.1021/acs.est.5b05833.

EEA. (2019). European Environment Agency, European Union Emission Inventory Report.

Environmental Protection Agency (EPA). (2014). Air Quality Index: A Guide to Air Quality and Your health. U.S. Environmental Protection Agency, Office of Air Quality Planning and Standards, https://www3.epa.gov/airnow/ aqi_brochure_02_14.pdf.

Garaga, R., Sahu, S. K., \& Kota, S. H. (2018). A review of air quality modeling studies in India: Local and Regional Scale. Current Pollution Reports, 4, 59-73. https://doi.org/ 10.1007/s40726-018-0081-0.

Gautam, S. (2020). The influence of COVID-19 on air quality in India: a boon or inutile. Bulletin of Environmental Contamination and Toxicology. https://doi.org/10.1007/ s00128-020-02877-y.

Ghorani-Azam, A., Riahi-Zanjani, B., \& Balali-Mood, M. (2016). Effects of air pollution on human health and practical measures for prevention in Iran. Journal of Research in Medical Sciences, 21, 65. https://doi.org/10. 4103/1735-1995.189646.

Gorai, A. K., Tchounwou, P. B., \& Mitra, G. (2017). Spatial variation of ground level ozone concentrations and its health impacts in an urban area in India. Aerosol and Air Quality Research, 17(4), 951. https://doi.org/10.4209/aaqr. 2016.08 .0374$.

Gorai, A. K., Tuluri, F., \& Tchounwou, P. B. A. (2014). GIS based approach for assessing the association between air pollution and asthma in New York State, USA. International Journal of Environmental Research and Public Health, 11, 4845-4869. https://doi.org/10.3390/ ijerph110504845.

Harrison, R. M., Thornton, C. A., Lawrence, R. G., Mark, D., Kinnersley, R., \& Ayres, J. G. (2002). Personal exposure monitoring of particulate matter, nitrogen dioxide, and carbon monoxide, including susceptible groups. Occupational and Environmental Medicine, 59(10), 671-679. https://doi.org/10.1136/oem.59.10.671.

He, G., Pan, Y., \& Tanaka, T. (2020). COVID-19, city lockdown, and air pollution: evidence from China. https://doi. org/10.1101/2020.03.29.20046649.

Heuss, J. M., Kahlbaum, D. F., \& Wolff, G. T. (2003). Weekday/ weekend ozone differences: What can we learn from them? Journal of the Air \& Waste Management Association, 53, 772-788. https://doi.org/10.1080/10473289.2003. 10466227.

Huang, X., Ding, A., Gao, J., Zheng, B., Zhou, D., Qi, X., Tang, R., Ren, C., Nie, W., Chi, X., Wang, J. (2020a). Enhanced secondary pollution offset reduction of primary emissions during COVID-19 lockdown in China. https://doi.org/10. 31223/osf.io/hvuzy.
Huang, C., Wang, Y., Li, X., Ren, L., Zhao, J., Hu, Y., et al. (2020b). Clinical features of patients infected with 2019 novel coronavirus in Wuhan, China. Lancet, 395, 497-506. https://doi.org/10.1016/s0140-6736(20)30183-5.

Isaifan, R. J. (2020). The dramatic impact of coronavirus outbreak on air quality: Has it saved as much as it has killed so far? Global Journal of Environmental Science and Management, 6(3), 275-288. https://doi.org/10.22034/GJESM. 2020.03.01.

Jing, G. (2020). Diary of a Life in Locked-Down Wuhan. https:// www.bbc.com/news/world-asia-china-51276656.

Karamchandani, P., Long, Y., Pirovano, G., Balzarini, A., \& Yarwood, G. (2017). Source-sector contributions to european ozone and fine PM in 2010 using AQMEII modeling data. Atmospheric Chemistry and Physics, 17, 5643-5664. https://doi.org/10.5194/acp-17-5643-2017.

Kerimray, A., Baimatova, N., Ibragimova, O. P., Bukenov, B., Kenessov, B., Plotitsyn, P., et al. (2020). Assessing air quality changes in large cities during COVID-19 lockdowns: The impacts of traffic-free urban conditions in Almaty, Kazakhstan. Science of the Total Environment, 730, 139179. https://doi.org/10.1016/j.scitotenv.2020. 139179.

Kyrkilis, G., Chaloulakou, A., \& Kassomenos, P. A. (2007). Development of an aggregate air quality index for an urban mediterranean agglomeration: relation to potential health effects. Environment International, 33, 670-676. https:// doi.org/10.1016/j.envint.2007.01.010.

Li, Q., Guan, X., Wu, P., Wang, X., Zhou, L., Tong, Y., et al. (2020). Early transmission dynamics in Wuhan, China, of novel coronavirus-infected Pneumonia. New England Journal of Medicine, 382, 1199-1207. https://doi.org/10. 1056/NEJMoa2001316.

Li, K., Jacob, D. J., Liao, H., Shen, L., Zhang, Q., \& Bates, K. H. (2019). Anthropogenic drivers of 2013-2017 trends in summer surface Ozone in China. Proceedings of the National Academy of Sciences, 116, 422-427. https://doi. org/10.1073/pnas.1812168116.

Li, M., Wang, T., Xie, M., Li, S., Zhaung, B., \& Chen, P. (2017). Impacts of aerosol- radiation feedback on local air quality during a severe haze episode in Nanjing Megacity, Eastern China. Tellus B, 69, 1339548. https://doi.org/10.1080/ 16000889.2017.133.9548.

Liu, J., Liao, X., Qian, S., Yuan, J., Wang, F., Liu, Y., et al. (2020a). Community transmission of severe acute respiratory syndrome coronavirus 2, Shenzhen, China. Emerging Infectious Diseases, 1, 1. https://doi.org/10.3201/ eid2606.200239.

Liu, F., Page, A., Strode, S.A., Yoshida, Y., Choi, S., Zheng, B., Lamsal, L.N., Li, C., Krotkov, N.A., Eskes, H., Vander, A.R. (2020b). Abrupt declines in tropospheric nitrogen dioxide over China after the outbreak of COVID-19. arXiv preprint arXiv:2004.06542.

Liu, H., Wang, X. M., Pang, J. M., \& He, K. B. (2013). Feasibility and difficulties of China's new air quality standard compliance: PRD case of $\mathrm{PM}_{2.5}$ and ozone from 2010 to 2025. Atmospheric Chemistry and Physics, 13, 12013-12027. https://doi.org/10.5194/acp-13-120132013.

Mahato, S., Pal, S., \& Ghosh, K. G. (2020). Effect of lockdown amid COVID-19 pandemic on air quality of the megacity 
Delhi, India. Science of the Total Environment. https://doi. org/10.1016/j.scitotenv.2020.139086.

Mason, R. O., Lind, D. A., \& Marchal, W. G. (1983). Statistics an introduction (pp. 368-383). New York: New York Harcourt Brace Jovanovich Inc.

Muhammad, S., Long, X., \& Salman, M. (2020). COVID-19 pandemic and environmental pollution: a blessing in disguise? Science of the Total Environment, 728, 138820. https://doi.org/10.1016/j.scitotenv.2020.138820.

Mukherjee, A., \& Agrawal, M. (2018). Air pollutant levels are 12 times higher than guidelines in Varanasi, India. Sources and transfer. Environmental Chemistry Letters, 16, 1009-1016. https://doi.org/10.1007/s10311-018-0706-y.

Murena, F. (2004). Measuring air quality over large urban areas: Development and application of an air pollution index at the urban area of Naples. Atmospheric Environment, 38, 6195-6202. https://doi.org/10.1016/j.atmosenv.2004.07. 023.

Murphy, J. G., Day, D. A., Cleary, P. A., Wooldridge, P. J., Millet, D. B., Goldstein, A. H., et al. (2007). The weekend effect within and downwind of sacramento-part 1: observations of ozone, nitrogen oxides, and VOC reactivity. Atmospheric Chemistry and Physics, 7, 5327-5339. https:// doi.org/10.5194/acp-7-5327-2007.

Nagendra, S. M. S., Venugopal, K., \& Jones, S. L. (2007). Assessment of air quality near traffic intersections in Bangalore city using air quality indices. Transportation Research Part D: Transport and Environment. https://doi. org/10.1016/j.trd.2007.01.005.

Newby, D. E., Mannucci, P. M., Tell, G. S., Bacarelli, A. A., Brook, R. D., Donaldson, K., et al. (2015). Expert position paper on air pollution and cardiovascular disease. European Heart Journal, 36(2), 83-93. https://doi.org/10.1093/ eurheartj/ehu458.

Ogen, Y. (2020). Assessing nitrogen dioxide $\left(\mathrm{NO}_{2}\right)$ levels as a contributing factor to the coronavirus (COVID-19) fatality rate. Science of the Total Environment. https://doi.org/10. 1016/j.scitotenv.2020.138605.

Ott, W. R. (1978). Environmental indices theory and practice (p. 48106). Ann Arbor: Ann Arbor Science Publishers Inc.

Saadat, S., Rawtani, D., \& Hussain, C. M. (2020). Environmental perspective of COVID-19. Science of the Total Environment. https://doi.org/10.1016/j.scitotenv.2020. 138870.

Sadeghi, M., Ahmadi, A., Baradaran, A., Masoudipoor, N., \& Frouzandeh, S. (2015). Modeling of the relationship between the environmental air pollution, clinical risk factors, and hospital mortality due to Myocardial infarction in Isfahan. Iran J Res Med Sci, 2(20), 757-762. https://doi. org/10.4103/1735-1995.168382.

Sahu, D., Kannan, G. M., \& Vijayaraghavan, R. (2014). Carbon black particle exhibits size dependent toxicity in human monocytes. Int J Inflam, 1, 827019. https://doi.org/10. 1155/2014/827019.

Sharma, S., Zhang, M., Jingsi, G. A., Zhang, H., \& Kota, S. H. (2020). Effect of restricted emissions during COVID-19 on air quality in India. Science of the Total Environment, 728, 138878. https://doi.org/10.1016/j.scitotenv.2020.138878.

Shrestha, A.M., Shrestha, U.B., Sharma, R., Bhattarai, S., Tran, H.N.T., \& Rupakheti, M. (2020). Lockdown caused by
COVID-19 pandemic reduces air pollution in cities worldwide. https://doi.org/10.31223/osf.io/edt4j.

Sicard, P., Marco, A. D., Agathokleous, E., Feng, Z., Xu, X., Paoletti, E., et al. (2020). Amplified ozone pollution in cities during the COVID-19 lockdown. Science of the Total Environment, 735, 139542. https://doi.org/10.1016/j. scitotenv.2020.139542.

Thom, G. C., \& Ott, W. R. (1976). A proposed uniform air pollution index. Atmospheric Environment, 10, 261-264.

Wang, P., Chen, K., Zhu, S., Wang, P., \& Zhang, H. (2020a). Severe air pollution events not avoided by reduced anthropogenic activities during COVID-19 outbreak. Resources, Conservation and Recycling, 158, 104814. https:// doi.org/10.1016/j.resconrec.2020.104814.

Wang, C., Horby, P. W., Hayden, F. G., \& Gao, G. F. (2020b). A novel coronavirus outbreak of global health concern. The Lancet, 395(10223), 470-473. https://doi.org/10.1016/ s0140-6736(20)30185-9.

Wang, Q., \& Su, M. (2020). A preliminary assessment of the impact of COVID-19 on environment-A case study of China. Science of the Total Environment. https://doi.org/ 10.1016/j.scitotenv.2020.138915.

Wang, Y., Ying, Q., Hu, J., \& Zhang, H. (2014). Spatial and temporal variations of six criteria air pollutants in 31 provincial capital cities in China during 2013-2014. Environment International, 73, 413-422. https://doi.org/10. 1016/j.envint.2014.08.016.

Wang, S., Yu, S., Yan, R., Zhang, Q., Li, P., Wang, L., et al. (2017). Characteristics and origins of air pollutants in Wuhan, China, based on observations and hybrid receptor models. Journal of Air Waste Management Association, 67, 739-753. https://doi.org/10.1080/10962247.2016. 1240724.

Weber, J. C., \& Lamb, D. R. (1970). Statistics and research in physical education. St. Louis: CV Mosby Co, 222, 59-64.

WHO. (2018). WHO global ambient air quality database (update 2018). World Health Organisation.

WHO. (2020a). Coronavirus disease 2019 (COVID-19) situation report -137 . World Health Organisation.

WHO. (2020b). Database: outdoor air pollution in cities; 20032010. Available from: WHO, 2020. Statement on the second meeting of the international health regulations (2005) emergency committee regarding the outbreak of novel coronavirus (2019-Ncov). Jan 30, 2020 (Accessed Feb 1, 2020). World Health Organisation.

WHO. (2020c). Report of the WHO-China joint mission on coronavirus disease 2019 (COVID-19). World Health Organisation.

WHO. (2020d). Air pollution. (Date accessed: April 8, 2020). World Health Organisation.

Wolff, G. T., Kahlbaum, D. F., \& Heuse, J. M. (2013). The vanishing ozone weekday/weekend effect. J. Air Waste Manage Assoc., 63, 292-299. https://doi.org/10.1080/ 10962247.2012.749312.

Wu, F., Zhao, S., Yu, B., Chen, Y. M., Wang, W., Song, Z. G., et al. (2020). A new coronavirus associated with human respiratory disease in China. Nature, 579(7798), 265-269. https://doi.org/10.1038/s41586-020-2008-3.

Yan, S., Cao, H., Chen, Y., Wu, C., Hong, T., \& Fan, H. (2016). Spatial and temporal characteristics of air quality and air pollutants in 2013 in Beijing. Environmental Science and 
Pollution Research, 23, 13996-14007. https://doi.org/10. 1007/s11356-016-6518-3.

Yuda, M. (2019). Asian countries rush to fight toxic air pollution. Accessed Jan 24, 2019.

Zhang, Y. L., \& Cao, F. (2015). Fine particulate matter $\left(\mathrm{PM}_{25}\right)$ in China at a city level. Scientific Reports, 5, 14884. https:// doi.org/10.1038/srep14884.
Zhu, Y., Xie, J., Huang, F., \& Cao, L. (2020). Association between short-term exposure to air pollution and COVID19 infection: Evidence from China. Science of the Total Environment. https://doi.org/10.1016/j.scitotenv.2020. 138704138704. 